\title{
35. BIOSTRATIGRAPHIC SYNTHESIS OF LEG 151, NORTH ATLANTIC-ARCTIC GATEWAYS ${ }^{1}$
}

\author{
Donna M. Hull, ${ }^{2}$ Lisa E. Osterman, ${ }^{3}$ and Jörn Thiede ${ }^{4}$
}

\begin{abstract}
Representatives of eleven microfossil groups were recovered from seven sites drilled during Leg 151 of the Ocean Drilling Program. These include planktonic and benthic foraminifers, calcareous nannofossils, ostracodes, diatoms, radiolarians, silicoflagellates, ebridians, actiniscidians, dinoflagellates and other palynomorphs (e.g., pollen and spores). Summaries of the biostratigraphic contributions presented in this volume are combined with shipboard reports to produce a synopsis of the biostratigraphic framework and chronostratigraphy for each site drilled on Leg 151 . Over $75 \%$ of the $3000 \mathrm{~m}$ of recovered material is Neogene in age; Quaternary and Pliocene sediments were recovered at all seven sites, and constitute the entire sequences drilled on the Yermak Plateau. Miocene sediments were recovered from four sites: (1) a middle to upper Miocene sequence in the southern portion of the Norwegian-Greenland Sea at Site 907 on the Iceland Plateau; (2) a short upper Miocene sequence overlying an unconformity on the Hovgård Ridge at Site 908 in the Fram Strait; (3) a very thick sequence (over 700 $\mathrm{m}$ ) of lower?/middle to upper Miocene dinoflagellate-rich sediments at Site 909, adjacent to Site 908; and (4) a wash core taken at Site 913 on the East Greenland Margin with middle to upper Miocene sediments in the western portion of the basin. Short sequences of Paleogene sediment were recovered from two sites, Site 908 (late early to early late Oligocene) on the Hovgård Ridge (Fram Strait) and Site 913 (early Eocene to earliest Oligocene) on the East Greenland Margin.
\end{abstract}

\section{INTRODUCTION}

Leg 151 of the Ocean Drilling Program (ODP) reached the most northern latitudes ever drilled by either the Deep Sea Drilling Project (DSDP) or ODP, recovering $3014.2 \mathrm{~m}$ of core from seven sites in the Norwegian-Greenland Sea and Arctic Ocean proper (Fig. 1; Table 1). As with drilling in any region that is not well known, discoveries are exciting and interesting, but biostratigraphy is inevitably challenging. Tectonic evolution in the Norwegian-Greenland Sea has had a profound impact on paleoceanographic evolution, resulting in extremely variable preservation of carbonate and silica and in faunas and floras that are in part endemic to the region. Two previous cruises, DSDP Leg 38 and ODP Leg 104, have conducted drilling in this area. Leg 38 sites recovered numerous discontinuous sequences by spot-coring in an era before magnetic polarity records were considered part of standard shipboard data collection. Consequently, these sequences were arranged in best possible stratigraphic order without definitive age control. Leg 104 used more recent drilling techniques and technology, employing continuous coring at all sites, but biostratigraphy and magnetostratigraphy suggested numerous hiatuses within the successions that have resulted in unresolved stratigraphic problems.

Data gathered from each new hole on Leg 151 have answered some of the questions and simultaneously raised new ones. As noted by Goll (1989), the development of zonations for the NorwegianGreenland Sea are still very much in their infancy (particularly for siliceous groups) and are less refined than those developed for tropi$\mathrm{cal}$ and temperate regions. Zonations for microfossil groups estab-

'Thiede, J., Myhre, A.M., Firth, J.V., Johnson, G.L., and Ruddiman, W.F. (Eds.), 1996. Proc. ODP, Sci. Results, 151: College Station, TX (Ocean Drilling Program).

${ }^{2}$ Programs in Geosciences, The University of Texas at Dallas, P.O. Box 830688 , Richardson, TX 75083-0688, U.S.A.dmhull@utdallas.edu

${ }^{3}$ Department of Paleobiology, NHB-121, Smithsonian Institution, Washington, D.C. 20560, U.S.A.

GEOMAR, Research Center for Marine Geosciences, Wischhofstraße 1-3, D. 24148 Kiel, Federal Republic of Germany. lished in the adjacent North Atlantic are not easily applied to the Norwegian-Greenland Sea, and little is known about pre-Quaternary Arctic faunas and floras. Some biostratigraphers working on Leg 151 material have refined previous zonations established for the region and created new zones (e.g., Koç and Scherer, Scherer and Koç, this volume). In other cases, the data are presented in a straightforward fashion as first and last occurrence events in lieu of using older zonal schemes that are not applicable to the data (e.g., Firth, this volume and Hull, this volume).

The fossil groups useful for biostratigraphy on Leg 151 include planktonic and benthic foraminifers (including agglutinated forms), calcareous nannofossils, ostracodes, diatoms, radiolarians, silicoflagellates, ebridians, actiniscidians, and dinoflagellates. Calcareous nannofossils and foraminifers have been most useful in dating Pliocene and Quaternary sediments. The most valuable fossil group for the Miocene appears to be dependent on a number of variables associated with the tectonic and paleoceanographic regimes, as well as the environment of preservation. For example, Site 907 on the Iceland Plateau contains a rich assemblage of Miocene siliceous microfossils, but, farther north at Site 909 in the Fram Strait, the Miocene consists of a long, continuous sequence barren of all fossils except dinoflagellates, other palynomorphs, and agglutinated foraminifers. However, a short upper Miocene sequence from Site 908 on the Hovgård Ridge, adjacent to Site 909 , includes diatoms. The older Paleogene sequence at Site 913 has the greatest diversity of preserved microfossils and is especially rich in siliceous fossils and dinoflagellates. The quality of age calibration varies among the different groups, but is far better in Neogene sequences than in the Paleogene (see individual chapters for further discussions).

Shipboard magnetostratigraphic interpretations remain the only set of interpretations for the magnetic data with the exception of Site 907. At this site, Koç and Scherer (this volume) offer a new interpretation which is discussed and illustrated in their paper and on Figure 2 herein. At the time Leg 151 set sail, the newest Geomagnetic Polarity Time Scale (GPTS) available was that of Cande and Kent (1992). Inasmuch as this is the GPTS used on the cruise and in the Initial Reports volume (Myhre, Thiede, Firth, et al., 1995), it is the GPTS used herein. 


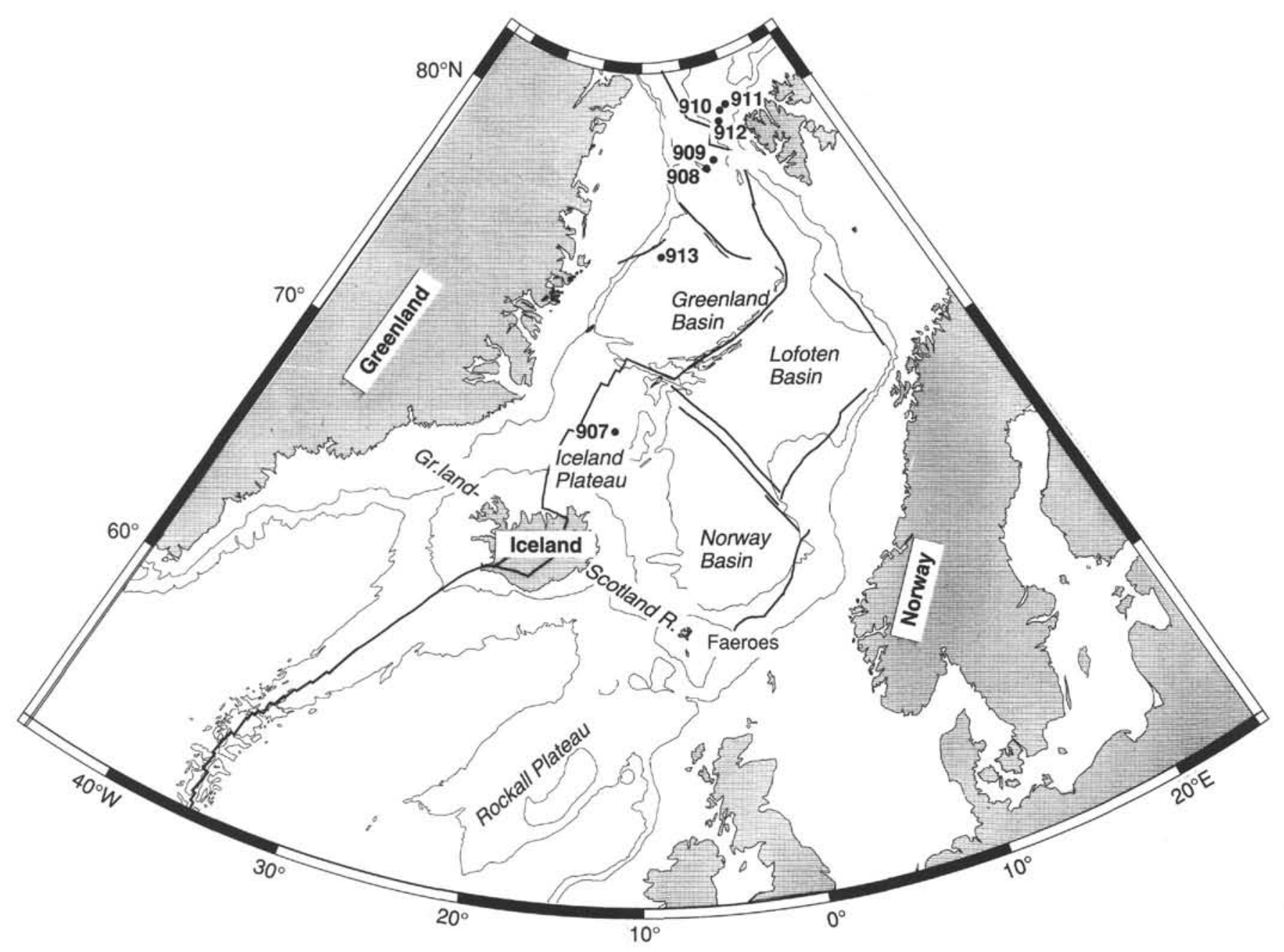

Figure 1. Locations of Sites 907-913 in the Norwegian-Greenland Sea.

\section{FOSSIL REPRESENTATION}

Eight fossil groups have been studied and documented for biostratigraphic purposes from Leg 151 sites. The distributions of these groups are discussed briefly below.

\section{Planktonic Foraminifers}

Quaternary planktonic foraminifers are present at all sites drilled on Leg 151, and are assigned to the Neogloboquadrina pachyderma sinistral Zone. Planktonic foraminifers are present in the Pliocene in Holes 907A, 909C, 910C, 910D, 911A, and 912C. These assemblages are assigned to two zones: the younger Neogloboquadrina sp. juv. Zone, and the Neogloboquadrina atlantica Zone. No occurrences older than Pliocene have been documented, with the exception of a single occurrence of the Miocene species, Globigerina scitula, near the base of Hole $909 \mathrm{C}$, and an assemblage of lower Eocene planktonic foraminifers in Hole 913B (Cores 151-913B-44R and 45R).

\section{Benthic Foraminifers}

Benthic foraminifers are present at all sites. Occurrences are nearly continuous in Hole 907A, where calcareous benthic foraminifers are found in the upper intervals and agglutinated forms in the lower part of the hole. Quaternary and Pliocene benthic foraminifers are rare in Hole 908A, but agglutinated species are well represented in
Table 1. Location of holes drilled on ODP Leg 151.

\begin{tabular}{lllrr}
\hline Hole & Latitude & Longitude & $\begin{array}{c}\text { Depth } \\
\text { (mwd) }\end{array}$ & $\begin{array}{r}\text { Length } \\
\text { (mbsf) }\end{array}$ \\
\hline $907 \mathrm{~A}$ & $69^{\circ} 14.989^{\prime} \mathrm{N}$ & $1^{\circ} 41.894^{\prime} \mathrm{E}$ & 1800.8 & 224.1 \\
$908 \mathrm{~A}$ & $78^{\circ} 23.112^{\prime} \mathrm{N}$ & $1^{\circ} 21.637^{\prime} \mathrm{E}$ & 1273.6 & 344.6 \\
$908 \mathrm{~B}$ & $78^{\circ} 23.125^{\prime} \mathrm{N}$ & $1^{\circ} 21.644^{\prime} \mathrm{E}$ & 1273.0 & 83.4 \\
$909 \mathrm{~A}$ & $78^{\circ} 35.065^{\prime} \mathrm{N}$ & $3^{\circ} 4.378^{\prime} \mathrm{E}$ & 2519 & 92.5 \\
$909 \mathrm{~B}$ & $78^{\circ} 35.065^{\prime} \mathrm{N}$ & $3^{\circ} 4.378^{\prime} \mathrm{E}$ & 2519.1 & 135.1 \\
$909 \mathrm{C}$ & $78^{\circ} 35.096^{\prime} \mathrm{N}$ & $3^{\circ} 4.222^{\prime} \mathrm{E}$ & 2518 & 1061.8 \\
$910 \mathrm{~A}$ & $80^{\circ} 15.882^{\prime} \mathrm{N}$ & $6^{\circ} 35.405^{\prime} \mathrm{E}$ & 556.4 & 35 \\
$910 \mathrm{~B}$ & $80^{\circ} 15.876^{\prime} \mathrm{N}$ & $6^{\circ} 35.451^{\prime} \mathrm{E}$ & 557.0 & 15.6 \\
$910 \mathrm{C}$ & $80^{\circ} 15.896^{\prime} \mathrm{N}$ & $6^{\circ} 35.430^{\prime} \mathrm{E}$ & 556.4 & 507.4 \\
$910 \mathrm{D}$ & $80^{\circ} 15.881^{\prime} \mathrm{N}$ & $6^{\circ} 35.424^{\prime} \mathrm{E}$ & 567.7 & 160.6 \\
$911 \mathrm{~A}$ & $80^{\circ} 28.466^{\prime} \mathrm{N}$ & $8^{\circ} 13.640^{\prime} \mathrm{E}$ & 901.6 & 505.8 \\
$911 \mathrm{~B}$ & $80^{\circ} 28.476^{\prime} \mathrm{N}$ & $8^{\circ} 13.636^{\prime} \mathrm{E}$ & 901.0 & 112.1 \\
$911 \mathrm{C}$ & $80^{\circ} 28.485^{\prime} \mathrm{N}$ & $8^{\circ} 13.637^{\prime} \mathrm{E}$ & 902.0 & 127.9 \\
$912 \mathrm{~A}$ & $79^{\circ} 57.557^{\prime} \mathrm{N}$ & $5^{\circ} 27.360^{\prime} \mathrm{E}$ & 1036.8 & 145.4 \\
$912 \mathrm{~B}$ & $79^{\circ} 57.553^{\prime} \mathrm{N}$ & $5^{\circ} 27.397^{\prime} \mathrm{E}$ & 1037.5 & 40.5 \\
$912 \mathrm{C}$ & $79^{\circ} 57.523^{\prime} \mathrm{N}$ & $5^{\circ} 27.363^{\prime} \mathrm{E}$ & 1036.6 & 209.1 \\
$913 \mathrm{~A}$ & $75^{\circ} 29.344^{\prime} \mathrm{N}$ & $6^{\circ} 56.8^{\prime} \mathrm{W}$ & 3318.6 & 103.6 \\
$913 \mathrm{~B}$ & $75^{\circ} 29.356^{\prime} \mathrm{N}$ & $6^{\circ} 56.810^{\prime} \mathrm{W}$ & 3318.4 & 770.3 \\
\hline
\end{tabular}

Note: $\operatorname{mwd}=$ meters water depth.

Oligocene sediments (Turrilina alsatica Assemblage). Four assemblages of agglutinated benthic foraminifers have been established by Osterman and Spiegler (this volume) in the Miocene at Site 909 (Hole 909C), underlying the Pliocene and Quaternary Melonis zaandamae Zone. Quaternary and Pliocene sequences recovered in Sites 910 through 913 have almost continuous recovery of calcareous 


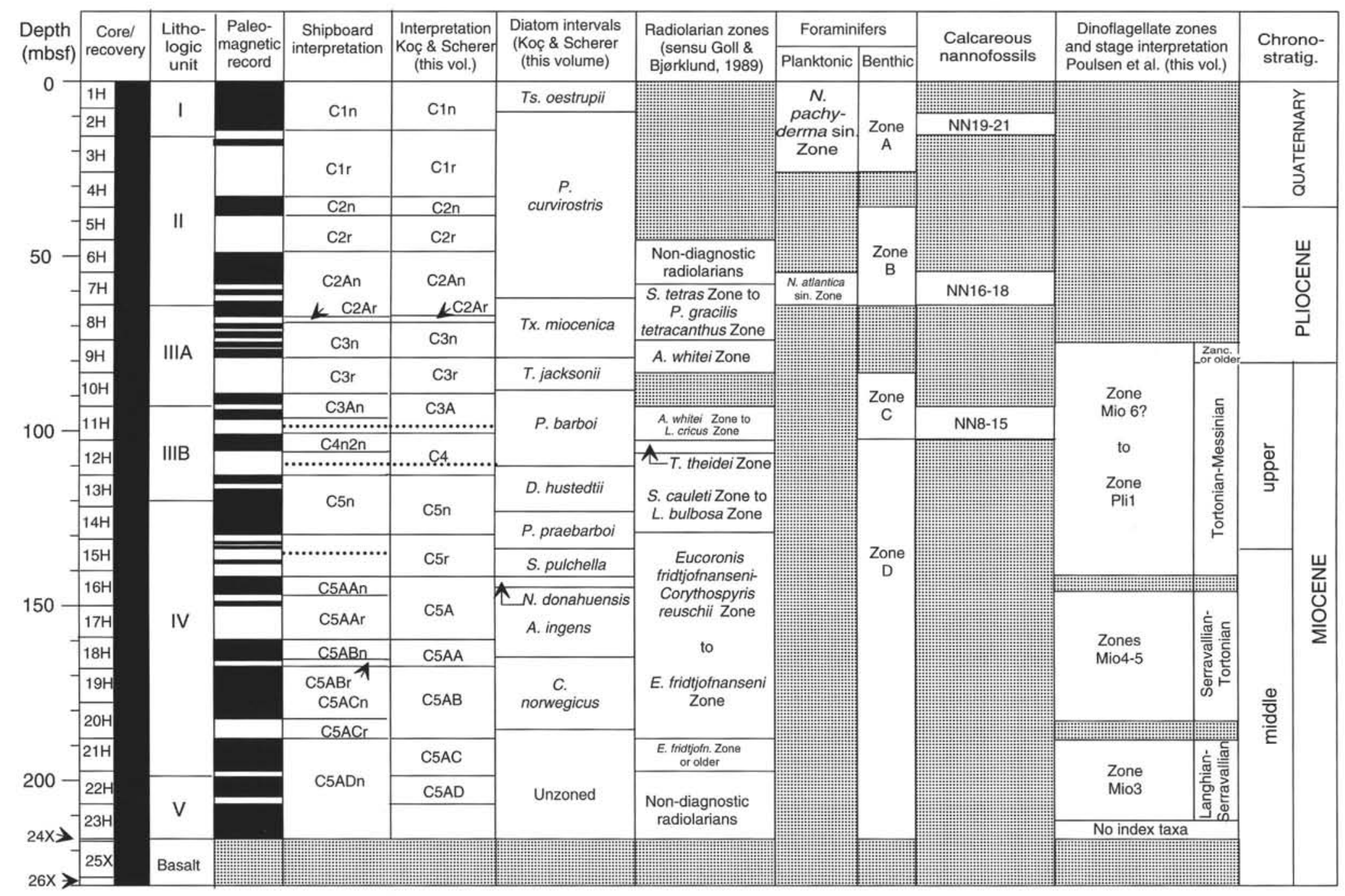

Figure 2. Biostratigraphic synthesis of Hole 907A. Gray dot-pattern indicates intervals that are barren or lack data. Magnetic polarity record and information for placement of radiolarian, foraminiferal, and calcareous nannofossil zones is from Chapter 5 in Initial Reports volume (Myhre, Thiede, Firth, et al., 1995); dotted lines indicate suggested hiatuses. Under "Core Recovery," black indicates recovery, white indicates no recovery. 
benthic foraminifers, although the Pliocene specimens at Site 911 include numerous reworked specimens. Finally, lower to upper Eocene, lower Oligocene, and Miocene material from Site 913 has yielded another succession of agglutinated benthic foraminifer assemblages (Osterman and Spiegler, this volume).

\section{Calcareous Nannofossils}

Calcareous nannofossils are present in Quaternary and Pliocene sediments at all sites. The longest continuous nannofossil-bearing sequences are on the Yermak Plateau (Sites 910, 911, and 912), in particular at Site 911, where Sato and Kameo (this volume) have dated numerous horizons, based on correlations between magnetostratigraphy, Yermak Plateau sites, and Pliocene sections in the North Pacific. Older nannofossil occurrences are found in Hole 907A (Zones NN815; upper Miocene) and in Hole 908A (NP20-25 Zones; Oligocene).

\section{Diatoms}

Neogene diatoms were recovered from Sites 907, 908, 912, and 913. The most continuous and best preserved occurrence is in Hole 907A, where a section of middle Miocene to Holocene diatoms has been documented and calibrated to the GPTS by Koç and Scherer (this volume). The remaining diatom occurrences are from much shorter intervals and were documented shipboard only (Myhre, Thiede, Firth, et al., 1995). They are: (1) Hole 908A, Sample 151908A-17X-4, 2-4 cm, assigned to the T. kryophila Zone; (2) Hole 912A, Sample 151-912A-13X-CC (126.1 mbsf), assigned questionably to the Proboscia barboi Zone; and (3) Hole 913B, Sample 151913B-19W-CC, ranging from the G. tenue to A. ingens Zone of Schrader and Fenner (1976).

Paleogene diatoms were observed in Hole 908A and Hole 913B. An assemblage of upper lower to lower upper Oligocene diatoms assigned to three zones, two of them new, has been documented by Scherer and Koç (this volume) from Hole 908A. The diatom-bearing material extends from Sample 151-908A-23X-5, 2-3 cm (212.3 mbsf) to Sample 151-908A-34X-5, 5-6 cm (302.7 mbsf). In Hole 913B, diatom-rich sediments range from Cores $151-913 \mathrm{~B}-24 \mathrm{R}$ to $27 \mathrm{R}$; a new diatom zone, Actinoptychus irregularis, spans this interval (Scherer and Koç, this volume). Rare pyritized diatoms are reported from Sample 151-908A-32R-CC (Myhre, Thiede, Firth, et al., 1995).

\section{Radiolarians}

The only significant occurrence of Neogene radiolarians in Leg 151 material is in Hole 907A from Samples 151-907A-6H-CC to $23 \mathrm{H}-\mathrm{CC}$. Preservation is variable in the Pliocene part of the section (from Cores $907 \mathrm{~A}-6 \mathrm{H}$ to $11 \mathrm{H}$ ) and includes several barren intervals, but improves downhole in the upper and middle Miocene. Of minor note are rare occurrences of Miocene to Pliocene radiolarians in Samples 151-910C-13R-CC and 151-909B-9H-CC (Myhre, Thiede, Firth, et al., 1995).

Paleogene radiolarians were recovered from Sites 908 and 913. At Site 908, radiolarians enter the section in Core 151-908A-20X and continue downhole to Sample 151-908A-34X-CC. Preservation and abundance vary widely throughout this sequence, and the fauna is composed of non-age diagnostic forms (e.g., lithelids and actinommids) among rare age-diagnostic regional and cosmopolitan species (Hull, this volume). A moderately to well-preserved succession of middle Eocene to lower Oligocene radiolarians is present in Hole 913B from Cores 151-913B-23R to 32R (Hull, this volume).

\section{Silicoflagellates}

Silicoflagellates were noted in shipboard reports, but with the exception of briefly documenting their presence, no further analyses were conducted (Myhre, Thiede, Firth, et al., 1995). Post-cruise studies have been undertaken on material from Holes 908A and 913B by Locker (this volume). In general, silicoflagellates co-occur with diatoms and radiolarians in most biosiliceous sequences. In Hole 908A, silicoflagellates have been found from Section 151-908A-17X-1 to 908A-35X-4. Part of this interval is assigned to the Cannopilus hemisphaericus Zone; the remainder is unzoned. Silicoflagellates occur in Hole 913B in Cores 151-913B-19W and 151-913B-24R to $27 R$.

\section{Ebridians}

Ebridians were noted in shipboard studies at Site 913 only (Myhre, Thiede, Firth, et al., 1995). Post-cruise, they have been studied in detail in both Holes 908A and 913B. In Hole 908A, ebridians and actiniscidians are most abundant between Samples 151-908A-21X-1, $56-57 \mathrm{~cm}$, to $35 X-4,9-10 \mathrm{~cm}$. The appearances of these siliceous flagellates in Hole 913B are very similar to the silicoflagellates. Core 913B-19W is dominated by two species of ebridians. A highly diversified assemblage of actiniscidians and ebridians is present from Sample 151-913B-24R-4, 111-114 cm, to $27 \mathrm{R}-2,113-117 \mathrm{~cm}$, and a few undiagnostic ebridians are present in the lower part of Core 913B27R.

\section{Dinoflagellates}

Dinoflagellates are present in sediments at all sites drilled on Leg 151. Shipboard analyses were conducted for preliminary age determinations at all sites except Site 911 (Myhre, Thiede, Firth, et al., 1995). Post-cruise detailed dinoflagellate studies have been completed for Holes 907A, 908A, 909C, and the Miocene of Hole 913B by Poulsen et al. (this volume). Firth (this volume) has documented over 250 taxa of dinoflagellates from the Paleogene of Site 913. In Hole 907A, Miocene and Pliocene dinoflagellate cysts are present from Core 151-907A-23H to 907A-10H (216.4 to $84.75 \mathrm{mbsf}$ ). In Hole 908A, they extend from Core 151-908A-37X to the top of Core 151908A-8H (342.2 to $63.4 \mathrm{mbsf})$. In Hole 909C, Cores 151-909C-103R to $27 \mathrm{R}$ contain dinoflagellate cysts, and finally, Poulsen et al. examined Core 151-913B-19W. These authors also document reworking of Jurassic to Paleogene dinoflagellates in Hole 907A, at two separate levels in 909C (923.4 and $940 \mathrm{mbsf}$ ), and of mid-Cretaceous dinocysts in Oligocene to Miocene samples at Site 908. Firth (this volume) also notes the presence of reworking of dinoflagellates in Hole 913B.

\section{SITE SUMMARIES}

\section{Site 907}

Site 907, drilled on the Iceland Plateau, serves as the midpoint in an east-west regional transect in the southern part of the NorwegianGreenland Sea (Table 1; Figs. 1, 2). The purpose of drilling this transect is to study the history of water exchange between the Norwegian-Greenland Sea and the surrounding bodies of water. This history is determined in part by monitoring the input of ice-rafted debris (IRD), carbonate, and biosilica into the sedimentary succession. It was also hoped that the site would provide an opportunity for conducting high-resolution Neogene biostratigraphy for siliceous, calcareous and organic microfossils. However, only one hole was drilled at this site before the crew was forced to cease operations. Site 907 was revisited and several additional holes were drilled on Leg 162.

Hole 907A consists of $224.1 \mathrm{~m}$ of middle Miocene to Holocene dark grayish brown to green-gray unlithified silty clay and clayey silt overlying middle Miocene crust (Fig. 2). Core 151-907A-1H to the uppermost part of Core 151-907A-5H are assigned to the Quaternary ( 0 to $37 \mathrm{mbsf}$ ); Pliocene sediments extend downhole to Core 151- 
907A-9H (83 mbsf) and upper Miocene faunas and floras to the top of Core 151-907A-15H (130.8 mbsf). Middle Miocene sediments are present to the base of Core 151-907A-23H (216.3 mbsf). One of the most important results of Hole 907A is the acquisition of what appears to be an excellent magnetostratigraphic record extending from the middle Miocene to the Holocene. This is especially important inasmuch as no magnetic polarity records were collected on Leg 38 and the records collected on Leg 104 may contain numerous hiatuses in the Neogene and the interpretation remains problematic (Eldholm, Thiede, Taylor, et al., 1987; Bleil, 1989). The upper $100 \mathrm{~m}$ of the sequence in Hole 907A correlate well to the GPTS, but the magnetostratigraphy is probably discontinuous below $100 \mathrm{mbsf}$. There are two interpretations of the magnetic polarity record from Hole 907A. The first is the shipboard interpretation (Myhre, Thiede, Firth, et al., 1995; see Fig. 2 herein), which indicates three hiatuses in the record: (1) in Core 151-907A-11H (between Chrons C3An and C4n2n); (2) in Core 151-907A-12H (between Chrons C4n2n and C5n); and (3) in Core 151-907A-15H (between Chrons C5n and C5AAn). The second interpretation is presented by Koç and Scherer (this volume; see Fig. 1 of Koç and Scherer and Fig. 2 in this chapter). The latter version is similar to the shipboard interpretation with the exception that the third hiatus has been removed and the magnetostratigraphy below $140 \mathrm{mbsf}$ reinterpreted accordingly. According to both interpretations, Hole 907A extends back to at least Chron 5 AD (14.8 Ma; Cande and Kent, 1992). However, ${ }^{40 / 39} \mathrm{Ar}$ whole-rock analyses of basalts from Core 151-907A-26X have indicated a younger age of $13.2 \pm 0.3$ $\mathrm{Ma}$ (Davis and McIntosh, this volume). Subsequent studies from Leg 162 may resolve these differences. Regardless of these problems, operations at this site on Leg 151 have produced one of the most continuous paleomagnetic records thus far from the Norwegian-Greenland Sea.

Planktonic foraminifers in Cores 151-907A-1H through $3 \mathrm{H}(26.3$ mbsf) are assigned to the Quaternary Neogloboquadrina pachyderma sinistral Zone; Cores 151-907A-4H through $6 \mathrm{H}$ (26.3 to $54.8 \mathrm{mbsf}$ ) are barren of both planktonic and benthic foraminifers. Sample 151907A-7H-CC (64.3 mbsf) yielded planktonics assignable to the Pliocene Neogloboquadrina atlantica sinistral Zone (Myhre, Thiede, Firth, et al., 1995), but this is the last occurrence of planktonic foraminifers at this site. Benthic foraminifers are more abundant than planktonic and are present throughout Hole 907A. The Quaternary "Zone A" is recognized from Core 151-907A-1H to Core 151-907A$3 \mathrm{H}$. This zone contains Eponides umbonatus, which is found in Norwegian-Greenland Sea sediments younger than Isotope Stage 13, and Bolivina arctica, an endemic species from the Arctic Ocean. The latter is dominant on the Vøring Plateau in sediments deposited during Isotope Stages 16-18. Pliocene Zone B (Cores 151-907A-7H to the top of $8 \mathrm{H} ; 54.8$ to $64.3 \mathrm{mbsf}$ ) is characterized by abundant Cassidulina teretis and includes Cibicides grossa in the lower part. Both species are known from Pliocene sediments in the Arctic Ocean (King, 1983; Knudsen and Asbjörnsdottir, 1991). Quaternary and Pliocene ages provided by the foraminifers are supported by calcareous nannofossils and magnetostratigraphy.

The Pliocene/Quaternary boundary has been placed, on the basis of magnetostratigraphy, at the top of Core $151-907 \mathrm{~A}-5 \mathrm{H}$ at approximately 37 mbsf in the middle of the Olduvai Event (in Chron C2n; Cande and Kent, 1992). This boundary lies within an interval which is barren of microfossils. Rare diatoms assignable to the P. curvirostris Interval (Koç and Scherer, this volume) are present, but do not provide any further age constraint.

Below 65 mbsf, biogenic silica and organic material become increasingly dominant, and age determinations based on calcareous microfossils give way in large part to ages provided by diatoms, radiolarians, dinoflagellates, and, to a lesser extent, by benthic foraminifers. Benthic foraminiferal Zone C (Cores 151-907A-10H and $11 \mathrm{H}$; 83.3 to $102.3 \mathrm{mbsf}$ ) is characterized by the upper Miocene foramini- fers Cibicides kullenbergi and Epistominella exigua. Agglutinated foraminifers, which are middle Miocene in age elsewhere at high latitudes, are found from Cores $151-907 \mathrm{~A}-12 \mathrm{H}$ to $23 \mathrm{H}$ (102.3 to 216.3 $\mathrm{mbsf}$ ) and characterize Zone D. Included in these assemblages are the species Martinottiella communis, Spirosigmoilinella sp., and Spiroloccamina sp.

Koç and Scherer (this volume) have defined 11 biostratigraphic "Intervals" based on 32 diatom events in Hole 907A. These diatom events are calibrated to a reinterpretation of the magnetic polarity record of Hole $907 \mathrm{~A}$ (see discussion above), and then to the GPTS of Cande and Kent (1992) to provide numerical age estimates for these events and intervals. This is thought to have produced an improved magnetobiochronologic framework for diatom events in the Norwegian-Greenland Sea. Radiolarian zones illustrated on Figure 2 are based on shipboard reports only (Myhre, Thiede, Firth, et al., 1995). The fauna bears strong resemblance to assemblages documented in the Iceland and Norwegian seas on DSDP Leg 38 (Bjørklund, 1976). An attempt was made to apply the radiolarian zonation of Goll and Bjørklund (1989) that was developed on the Vøring Plateau (Leg 104), but many of the markers used in that zonation are absent on the Iceland Plateau, resulting in broadly defined assemblages and weaker age control (Myhre, Thiede, Firth, et al., 1995). Post-cruise studies initiated by R. Goll, however, show good potential for re-calibrating the Norwegian-Greenland Sea radiolarian events to the GPTS (R. Goll, unpubl. data, pers. comm., 1995).

Poulsen et al. (this volume) analyzed 49 samples from $141 \mathrm{~m}$ of cored sediment in the lower part of the succession for spores, pollen, and dinocysts. The ages provided by their studies are in general agreement with other fossil groups below $65 \mathrm{mbsf}$, but they introduce a few complexities into the placement of sub-stage boundaries. The lowermost sample ( $216.4 \mathrm{mbsf}$ ) is assigned to the Langhian or older (middle Miocene), based on the presence of Batiacasphaera sphaeri$c a$ that suggests only that there is no pre-Miocene present (Head, pers. comm., 1994, in Poulsen et al., this volume).

The Miocene/Pliocene boundary in this chapter is placed at the base of Core 151-907A-9H in Chron C3r, just below the last occurrence of the diatom Thalassiosira jacksonii (approximately $83 \mathrm{mbsf}$ ). Additional diatom studies from new sites with good paleomagnetic records are needed to confirm the usefulness of $T$. jacksonii as a significant marker for the placement of the Miocene/Pliocene boundary, but as of this writing, it appears to be one of the few taxa with a first or last occurrence associated with the boundary at Site 907. Dinoflagellate studies herein indicate only that this interval is "Zanclean or older."

The middle/upper Miocene boundary is slightly more problematic, and its placement represents a reasonable compromise among the data. In this chapter, it is placed in the top of Core 151-907A-15H at the base of the diatom $P$. praebarboi Interval (130.8 mbsf), which is marked by the last occurrence of Synedra pulchella within Chron C5r (sensu Koç and Scherer, this volume). Conflicting evidence comes from dinoflagellates and benthic foraminifers. Benthic foraminifer Zone D extends from Samples 151-907A-11H-CC to 151-907A$24 \mathrm{X}-\mathrm{CC}$ and is composed of Miocene agglutinated foraminifers. This suggests that the boundary could be as high as the base of Core 151$907 \mathrm{~A}-11 \mathrm{H}$. However, benthic foraminifers are very diachronous in this region and may not be useful in placing stratigraphic boundaries. Dinoflagellates indicate that the boundary could be lower, in an interval between Cores 151-907A-16H and 20H (182.9-144.9 mbsf). Poulsen et al. (this volume) assign this interval to the SerravallianTortonian (upper middle to lower upper Miocene) based on the highest occurrence of Palaeocystodinium golzowense. Inasmuch as dinoflagellate tops are often reworked, other microfossil groups indicate middle Miocene below Core 151-907A-14H, and magnetostratigraphy in both interpretations (Myhre, Thiede, Firth, et al., 1995; Koç and Scherer, this volume) suggests middle Miocene below 
Core $151-907 \mathrm{~A}-15 \mathrm{H}$, it is suggested that the interval between 182.9 and $144.9 \mathrm{mbsf}$ lies in the older part of Poulsen et al.'s age determination.

\section{Site 908}

Site 908 was drilled on the Hovgård Ridge west of Svalbard (Table 1; Figs. 1,3). The site was selected as the southernmost tiepoint in the northern gateway transect through the Fram Strait to study the history of water exchange between the Arctic Ocean and the Norwegian-Greenland Sea. It was also selected to determine the age and lithology of sediments in basins on the ridge crest, which provide insight into the post-submergence history of the Hovgard Ridge. Two holes were drilled at this site: Hole $908 \mathrm{~A}$, with a penetration depth of $344.6 \mathrm{~m}$ (91.1\% recovery) and Hole 908B, which reached $83.4 \mathrm{~m}$ ( $93.5 \%$ recovery).

Drilling at Site 908 recovered a sequence of upper Miocene to Quaternary fine-grained siliciclastic sediments (Lithologic Unit I) overlying an unconformity at $185 \mathrm{mbsf}$ (Fig. 3). This part of the succession has a few intervals of foraminifer- and nannofossil-bearing mud in the uppermost two cores in addition to erratically occurring dropstones and three distinct ash layers. Beneath the unconformity, an additional $159.6 \mathrm{~m}$ of biosilica-rich dark olive-gray to dark grayish brown silty clay were recovered, which have been assigned to the late early to early late Oligocene. Age-dating throughout the holes is based on planktonic and benthic foraminifers, calcareous nannofossils, diatoms (Scherer and Koç, this volume), silicoflagellates and ebridians (Locker, this volume), and dinoflagellates (Poulsen et al., this volume). The magnetic polarity record has been interpretable in the upper $180 \mathrm{mbsf}$, but below the unconformity contains a "noisy inclination record" which is very difficult to interpret (Myhre, Thiede, Firth, et al., 1995).

Planktonic foraminifers in the upper two cores of Holes 908A and $908 \mathrm{~B}$ are assignable to the $N$. pachyderma $\sin$. Zone. Three out of ten samples processed from these cores (Samples 151-908A-1H-1, 43$46 \mathrm{~cm} ; 1 \mathrm{H}-2,67-69 \mathrm{~cm}$; and $2 \mathrm{H}-3,135-139 \mathrm{~cm}$ ) have high abundances of $N$. pachyderma, suggesting interglacial periods. Calcareous nannofossils are characterized by very low species diversity and age-diagnostic taxa are rare to absent from this northern site. Samples 151-908A-1H-2, 50 cm, and 1H-2, $75 \mathrm{~cm}$, contain Emiliania huxleyi and are assignable to NN21. Sample 151-908A-2H-CC contains small species of Gephyrocapsa (e.g., G. ericsonii), and is assigned to NN19-20, although markers such as $P$. lacunosa are absent. Quaternary and Pliocene benthic foraminifers are present throughout the upper ten core catchers in Hole 908A, but they are rare with scattered occurrences (Myhre, Thiede, Firth, et al., 1995).

Poulsen et al. (this volume) report upper Miocene (Messinian) to Pliocene (Zanclean) dinoflagellates from Sections 151-908A-15X-2 to $8 \mathrm{H}-01$ (132-63 mbsf). Precise placement of the Quaternary/ Pliocene boundary is not possible based on dinoflagellate evidence, but it is tentatively given a range from the base of Core $151-908 \mathrm{~A}-6 \mathrm{H}$ ( $53 \mathrm{mbsf}$ ) to the top of Core 151-908A-8H (63 mbsf). This is in disagreement with the shipboard paleomagnetic interpretation, which shows the top of the Olduvai subchronozone at $95.3 \mathrm{mbsf}$, within the interval of Messinian to Zanclean dinoflagellates. However, polarity stratigraphy also shows three intervals of "indeterminate polarity" within the upper part of Site 908A. Biostratigraphic data at Site 908A may be more reliable than magnetostratigraphic. The Miocene/ Pliocene boundary is weakly constrained between 63 and $132 \mathrm{mbsf}$.

Between 132 mbsf and the unconformity at $185 \mathrm{mbsf}$, age dating is based primarily on dinoflagellates, supported by a brief appearance of diatoms. Poulsen et al. (this volume) have assigned sediments from 132 to $185 \mathrm{mbsf}$ to the Tortonian (upper Miocene) based on correlation between the Sites 908 and 909 . At 153 mbsf (Sample 151908A-17X-4, 2-4 cm), shipboard scientists discovered diatoms preserved directly above a white ash layer. According to shipboard re- ports (Myhre, Thiede, Firth, et al., 1995), the assemblage is assignable to the $T$. kryophila Zone. Based on the range of $T$. jacksonii by Koç and Scherer (this volume), this interval ranges in age from late Miocene to earliest Pliocene and supports dinoflagellate correlations.

The unconformity at $185 \mathrm{mbsf}$ was recognized by shipboard scientists by its visibility on seismic profiles, well logs, and biostratigraphy (Myhre, Thiede, Firth, et al., 1995). Studies by Poulsen et al. (this volume) indicate that the boundary can be placed more precisely in Section 151-908A-20X-5, between 106 and $137 \mathrm{~cm}$ (184.76 to $184.44 \mathrm{mbsf}$ ) based on palynology, the absence of Oligocene last occurrence datums, and good Miocene assemblages above $137 \mathrm{~cm}$. Thus, the hiatus represented by the unconformity spans the late late Oligocene (late Chattian) plus early and middle Miocene.

Dating of Unit II below the unconformity is based on diatoms, silicoflagellates, ebridians, dinoflagellates, and, to a lesser extent, on benthic foraminifers, calcareous nannofossils, and radiolarians (Fig. 3; Myhre, Thiede, Firth, et al., 1995; Scherer and Koç; Locker; Hull; and Poulsen et al., all in this volume). Poulsen et al. assigned Sections 151-908A-20X-5 to $27 \mathrm{X}-4$ (249.6 to $184.7 \mathrm{mbsf}$ ) directly underlying the unconformity to the early Chattian, and Sections 151-908A-27X4 to 37 X-2 (249.6 to 342.2 mbsf; nearly the base of Hole 908A) to the late Rupelian. Thus, Unit II is assigned to the late early to early late Oligocene.

Diatom studies by Scherer and Koç (this volume) support this age determination. Diatom abundance and preservation fluctuate widely throughout the $180-\mathrm{m}$ interval underlying the unconformity. The biostratigraphic interpretation of Scherer and Koç is based on comparisons of the assemblage in Hole 908A with others in the NorwegianGreenland Sea (e.g., Schrader and Fenner, 1976; Dzinoridze et al., 1978; Fenner, 1985) and other high-latitude areas. Two new diatom zones, the Sceptroneis fennerae Zone (lower to lower upper Oligocene, Sample 151-908A-23X-5, 2-3 cm, to $32 X-7,46-47 \mathrm{~cm}$ ) and the Cymatosira praecompacta Zone (lower Oligocene, Samples 151$908 \mathrm{~A}-33 \mathrm{X}-2,95-97 \mathrm{~cm}$, to $34 \mathrm{X}-3,85-86 \mathrm{~cm}$ ) are proposed by Scherer and Koç. A third zone, the Sceptroneis pupa Zone (lower upper Oligocene, Sample 151-908A-21X-2, 146-147 cm to 23X-2, 81$82 \mathrm{~cm}$; Schrader and Fenner, 1976), is revised.

Radiolarians in Unit II are extremely rare and poor to moderately preserved from Core 151-908A-20X to $34 \mathrm{X}$. Assemblages are dominated by actinommids and lithelids, which thus far have no biostratigraphic utility. There are a few species present which have known occurrences outside of the Norwegian-Greenland Sea (e.g., Corythospyris palmipodiscus, Pseudodictyophimus platycephalus), but these are rare and provide only modest age control (Hull, this volume).

Silicoflagellate and ebridian biostratigraphy is in slight disagreement with dinoflagellate and diatom age determinations. Paleogene silicoflagellate biostratigraphy is based primarily on the zonation developed by Bukry (1981); in addition, a series of first and last occurrence events has been developed by Locker (this volume), which are related to the time scale of Cande and Kent (1992). Many of these events are calibrated to nannofossil datums that are calibrated to the Cande and Kent magnetic polarity scale by Wei and Peleo-Alampay (1993). According to Locker (this volume), silicoflagellates from Sample 151-908A-21X-2, 56-57 cm, to $34 X-3,57-59 \mathrm{~cm}$, belong to the Cannopilus hemisphaericus Zone, which is thought to be upper Oligocene. Although the difference is not large, it should be noted that silicoflagellate and ebridian stratigraphy presented in this volume indicates that sediments in Hole 908A do not extend into the early Oligocene.

Benthic foraminifers and calcareous nannofossils are also present in the Oligocene of Hole 908A. Benthic foraminifers range from Core 151-908A-23X to $37 \mathrm{X}$ and consist of a mixed calcareous/agglutinated assemblage, which is similar to assemblages in Oligocene deposits of the North Sea (King 1983), Vøring Plateau (Osterman and Qvale, 1989), Labrador Sea (Miller et al., 1982), and Bay of Biscay (Miller, 1983). One of the more common forms in this assemblage is 


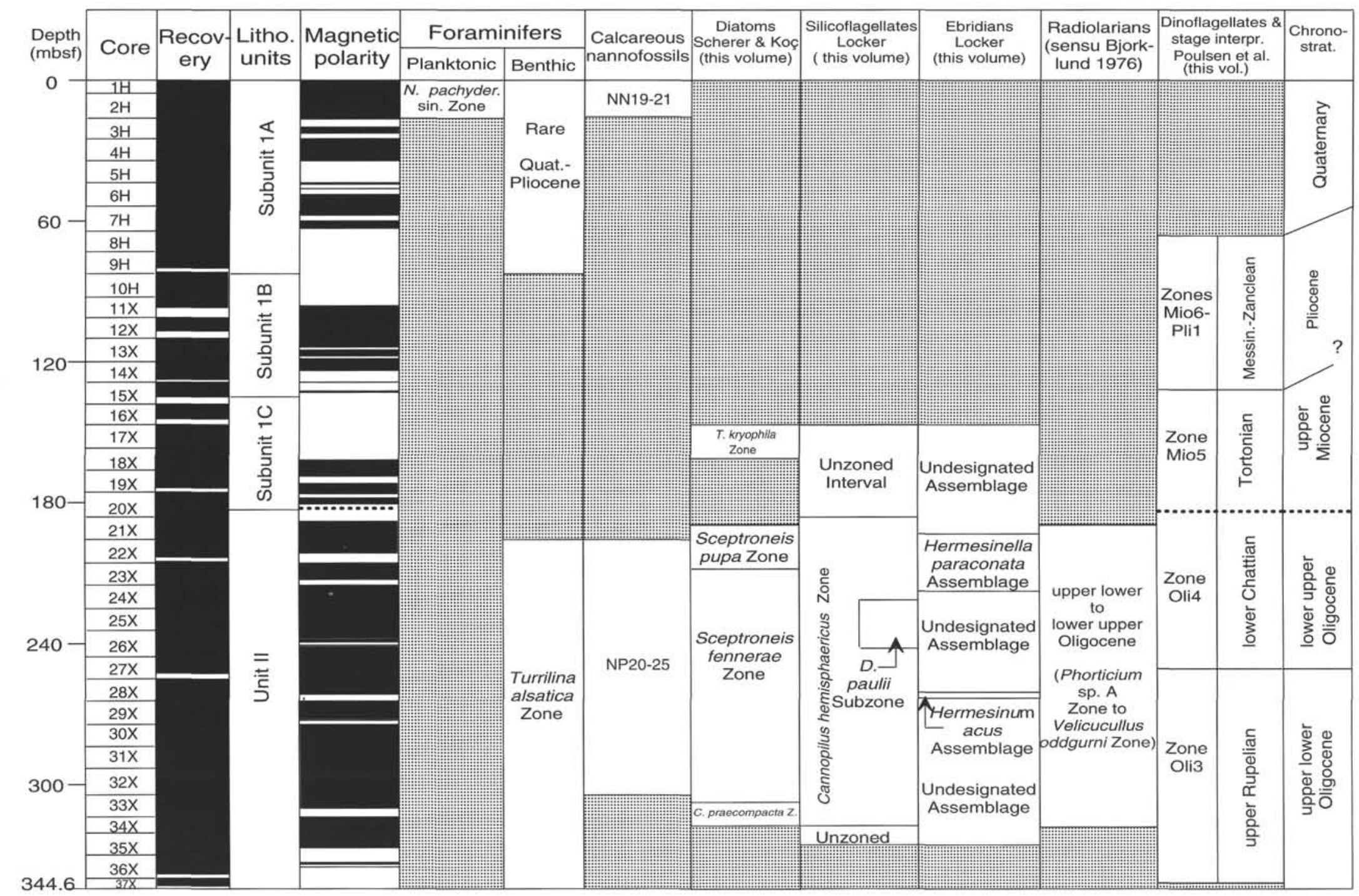

Figure 3. Biostratigraphic synthesis of Hole 908A. Magnetic polarity record and Quaternary/Pliocene data are from Chapter 6 in Initial Reports volume (Myhre, Thiede, Firth, et al., 1995). Other data as indicated from reports in this volume. See Figure 2 caption for pattern explanations. Vertical-line pattern indicates indeterminate polarity. 
Turrilina alsatica, which indicates low to intermediate oxygen in bottom waters (Kaiho, 1991). Agglutinated foraminifers are more abundant between Cores 151-908A-30X and 37X, and include $C y$ clammina and Rhizammina species. The calcareous nannofossil assemblage (Cores 151-908A-23X to 32X) is assigned herein to NP20NP25 on the basis of the continuous occurrences of Dictyococcites bisectus and Chiasmolithus altus (Sato and Kameo, this volume).

\section{Site 909}

Site 909 (Table 1; Figs. 1,4) was drilled in $2500 \mathrm{~m}$ of water on the Greenland-Spitsbergen Sill. This site was chosen to study the opening of the Fram Strait and the timing of deep- and shallow-water exchange between the Arctic Ocean and the Norwegian-Greenland Sea. The age control at Hole $909 \mathrm{C}$ is accomplished with planktonic foraminifers, calcareous nannofossils, and palynomorphs. Upper Pliocene to Miocene sediments are indicated from Samples 151909C-27R-CC to 50R-CC ( 345.3 to $566.6 \mathrm{mbsf}$ ).

The base of Hole $909 \mathrm{C}$ is constrained as earliest Miocene based on the occurrence of the calcareous nannofossil Helicosphaera carteri in Sections 151-909C-101R-2 through 102R-CC (Myhre, Thiede, Firth, et al., 1995). Palynomorphs also support a Miocene (Aquitanian?-Langhian?) age of the oldest sediments based on the occurrence in Sample 151-909C-103R-CC of Hystrichokolpoma sp. 2, which does not occur below the Miocene of Site 643 (Manum et al., 1989; Poulsen et al., this volume). Middle Miocene (Langhian) sediments occur between the first observation of Labyrinthodinium truncatum in Sample 151-909C-98R-CC (1020 mbsf) and the last observation of Apectodinium spiridoides in Sample 151-909C-92R-CC (992 mbsf; Poulsen et al., this volume).

Upper to middle Miocene (Langhian-Serravallian-Tortonian) material occurs from 151-909C-51R-CC to 82R-CC (573.01 to $867.88 \mathrm{mbsf}$ ), based on the first observation of Achomosphaera? andalousiensis in Sample 151-909C-82R-CC (867.8 mbsf) and the last observation of Palaeocystodinium golzowense in Sample 151-909C51R-CC (573.01 mbsf; Poulsen et al., this volume). Upper Pliocene to Miocene (Messinian-Zanclean) sediments are indicated from Samples 151-909C-27R-CC to 50R-CC (345.3 to $566.6 \mathrm{mbsf}$ ), based on the highest record of Recticulatosphaera actinocoronata in Sample 151-909C-27R-CC (Poulsen et al., this volume).

The majority of the agglutinated foraminiferal assemblage at Site 909 occurs in middle to upper Miocene sediments (1062.8 to 570 mbsf). Hole 909C contains an assemblage of agglutinated benthic foraminifers dominated by Reticulophragmium ex gr. torundidorsata and Reticulophragmium amplectens (Fig. 4; Osterman and Spiegler, this volume). Reticulophragmium amplectens is an Eocene species that has never been reported in sediments of Miocene age. Although reworking of the foraminiferal assemblage seems a likely explanation, Osterman and Spiegler (this volume) reject the possibility of reworking for these reasons: (1) substantial tectonic uplift would be required to allow the erosion of Eocene deep-water deposits and subsequent deposition into Miocene sediments; and (2) no other microfossils in this interval are reworked, and all indicate a Miocene age.

The agglutinated faunas have been divided into four assemblages (Fig. 4). From oldest to youngest these are: (1) the lower to middle Miocene RhabdamminalReophax assemblage (Samples 151-909C100R-CC to 103R-CC; 1048.4 to $1062.8 \mathrm{mbsf}$ ); (2) the middle Miocene Reticulophragmium ex gr. rotundidorsata and Reticulophragmium amplectens assemblage (Samples 151-909C-90R-CC to 100R-1, 95-99 cm; 952.4 to $1039.75 \mathrm{mbsf}$ ); (3) the middle Miocene Reticulophragmium amplectens assemblage (Samples 151-909C71R-CC, 95-99 cm to 87R-CC; 760.25 to $923.4 \mathrm{mbsf}$ ); and (4) the middle to upper Miocene Reticulophragmium ex gr. rotundidorsata assemblage (Samples 151-909C-51R-1, 76-78 cm, to 70R-CC; 605.86 to $759.3 \mathrm{mbsf})$.

Pliocene sediments are recognized by the occurrence of the planktonic foraminifer $N$. atlantica in Samples 151-909C-23R-CC to 151-
909C-9R-1, 86-88 cm, which agrees with both calcareous nannofossils and benthic foraminifers. Quaternary sediments are found throughout Hole 909A and 909B (Myhre, Thiede, Firth, et al., 1995).

\section{Site 910}

Site 910 was drilled on the Yermak Plateau northwest of Svalbard (Table 1; Figs. 1, 5). It was drilled as the shallow member of a bathymetric transect across the plateau to study pre- and post-glacial environments. The upper $67 \mathrm{~m}$ of Hole $910 \mathrm{C}$ is identified as Quaternary, but is plagued with poor recovery and the presence of one or more intervals of overconsolidated sediment (see Rack, this volume; Flower, this volume). The uppermost consolidated zone occurs at $19 \mathrm{mbsf}$ in Hole 910A, and can be assumed to be close to that depth in Hole $910 \mathrm{C}$. The Quaternary/Pliocene boundary is constrained within Core 151-910C-8R based on foraminifers and calcareous nannofossils. Sample 151-910C-8R-2, 20-23 cm (65.9 mbsf) contains a diverse benthic foraminiferal assemblage with no Cibicides grossa, and the planktonic foraminifer Neogloboquadrina pachyderma which indicates a Quaternary age (Osterman, this volume). Sample 151-910C8R-CC (73.8 mbsf) does not contain the Quaternary index calcareous nannofossils Gephyrocapsa caribbeanica and Gephyrocapsa oceanica and is assumed to be Pliocene in age (Sato and Kameo, this volume). Therefore the Quaternary/Pliocene boundary is placed between these two samples at $67 \mathrm{mbsf}$.

All microfossil groups present indicate that the interval from Sample 151-910C-11R-CC (102.8 mbsf) to the base of the hole (507.4 mbsf) is clearly of late Pliocene age (NN15-18; Myhre, Thiede, Firth, et al., 1995). The newly defined calcareous nannofossil Datum A (Sato and Kameo, this volume) occurs between Samples 151-910C-24R-CC and 151-910C-25R-CC (228.3 and $237.6 \mathrm{mbsf}$ ) and is believed to have occurred at $2.78 \mathrm{Ma}$, based on the paleomagnetic age of a similar event in the Pliocene sediments of Japan and nearby Site 911.

The base of Hole $910 \mathrm{C}$ is constrained to the late Pliocene based on calcareous nannofossils (Sato and Kameo, this volume), as well as ostracodes and benthic foraminifers. The presence of the ostracode Pterygocythereis vannieuwenhuisei in Samples 151-910C-45R-CC (429.3 mbsf) to 151-910C-43R-CC (410.78 mbsf; Cronin, this volume) indicates an age of at least $2.5 \mathrm{Ma}$ for these samples. The occurrence of Pacific benthic foraminifers, including Paracassidulina neocarinata, Globocassidulina grooviapetura, and Paracassidulina sagamenensis in Sample 151-910C-53R-CC (507.4 mbsf), indicates that it must have been deposited after the opening of the Bering Straits (Myhre, Thiede, Firth, et al., 1995). The age of the opening is believed to have occurred at approximately $3.0 \mathrm{Ma}$.

A sedimentation rate can be calculated for Hole $910 \mathrm{C}$ based on the two calcareous nannofossil datums ( $67 \mathrm{mbsf}$ at $1.757 \mathrm{Ma}$ and 233 mbsf at $2.78 \mathrm{Ma}$ ) and an estimated date of no older than late Pliocene $(<3.4 \mathrm{Ma})$ for the base of the hole. In the earliest late Pliocene $(507.4$ mbsf at 3.4 Ma to $233 \mathrm{mbsf}$ at $2.78 \mathrm{Ma}$ ), the minimum sedimentation rate was $44 \mathrm{~cm} / \mathrm{ka}$. In the late Pliocene, sediments are associated with glacial dropstones and the sedimentation rate drops to $16 \mathrm{~cm} / \mathrm{ka}$. The causes of these very high early late Pliocene sedimentation rates are the subject of future investigations.

\section{Site 911}

Site 911 contains Pliocene and Quaternary sediments (Table 1; Figs. 1, 6). The Pliocene/Quaternary boundary is placed between 217 and $217.5 \mathrm{mbsf}$ based on the occurrence of calcareous nannofossil Datum 12 (Sato and Kameo, this volume). Datum 12, defined by the lowest occurrence of calcareous nannofossils $G$. caribbeanica and $G$. oceanica, is situated above the Olduvai event in the Matuyama reversed Epoch, and traced to the Pliocene/Quaternary boundary at the type section at Vrica, Italy (Sato and Takayama, 1992). The depth of the Pliocene/Quaternary boundary is supported by paleomagnetics 


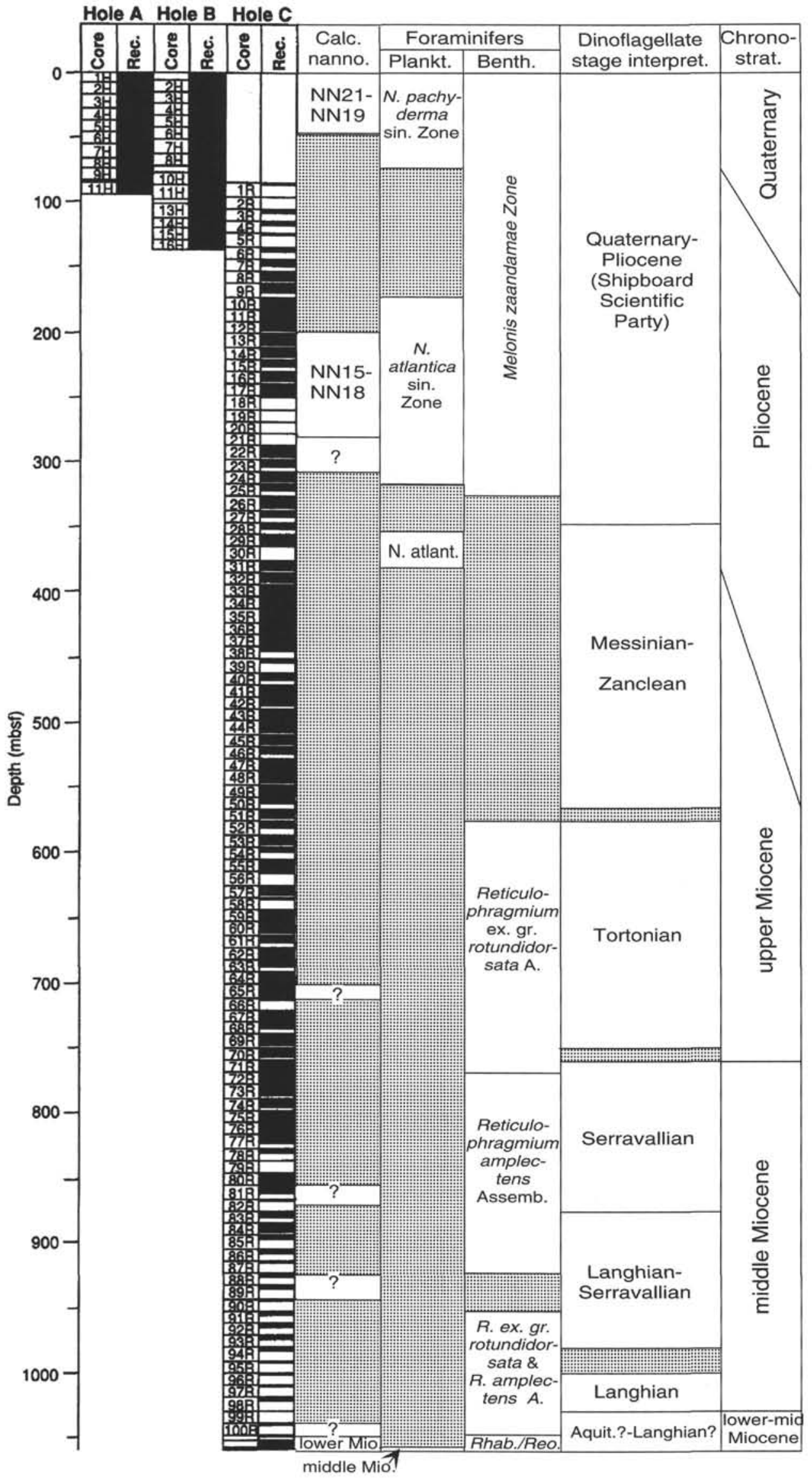

Figure 4. Biostratigraphic synthesis of Holes 909A, 909B, and 909C. Biostratigraphic data are from Chapter 7 in Initial Reports volume (Myhre, Thiede, Firth, et al., 1995), Osterman and Spiegler (this volume), Poulsen et al. (this volume), and Spiegler (this volume). See Figure 2 caption for pattern explanations. 
Figure 5. Biostratigraphic synthesis of Hole 910C. Biostratigraphic data are from Chapter 8 in Initial Reports volume (Myhre, Thiede, Firth, et al, 1995), Osterman (this volume), Spiegler (this volume) and Sato and Kameo (this volume). See Figure 2 caption for pattern explanations. Vertical-line pattern indicates indeterminate polarity.

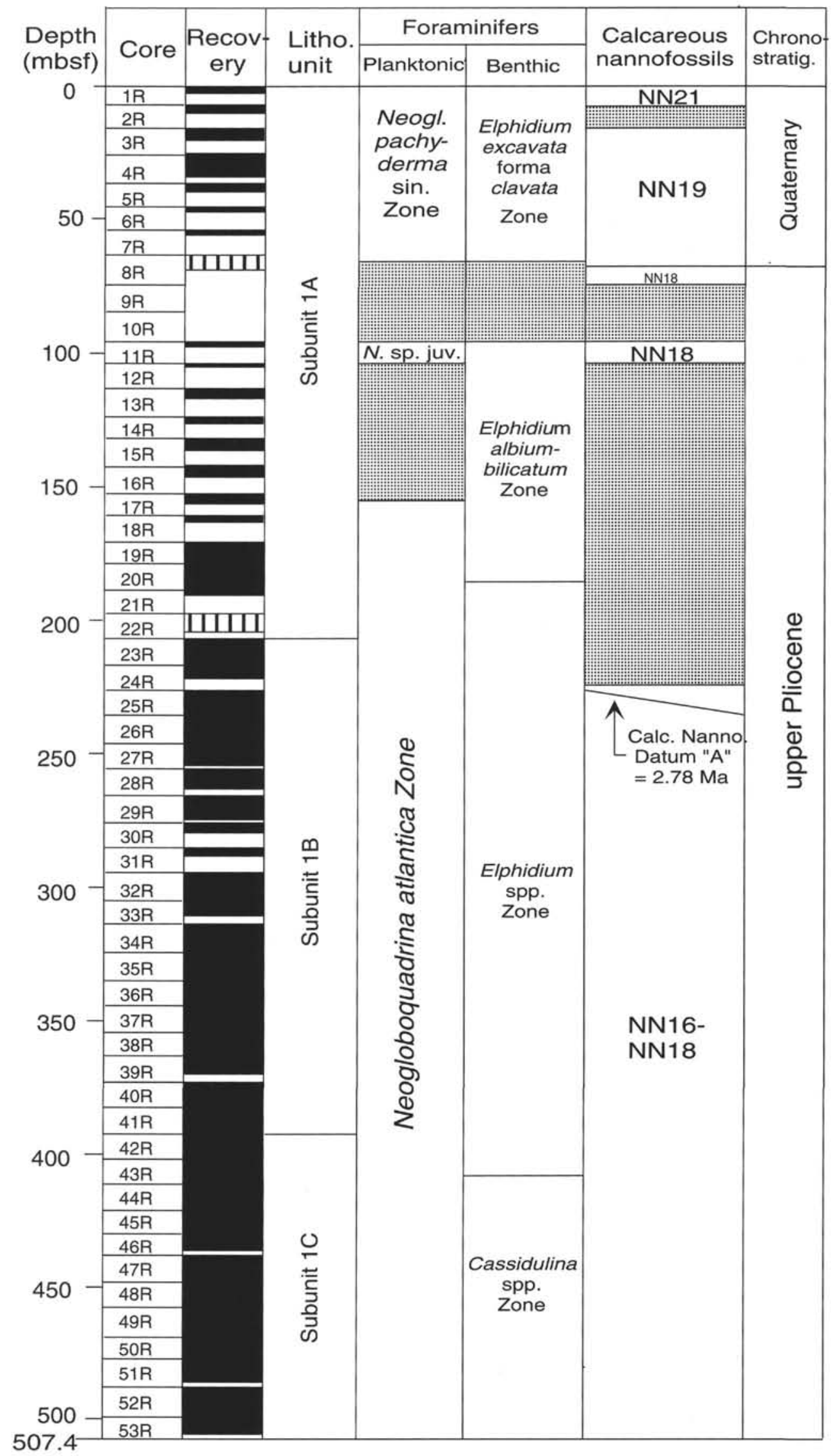




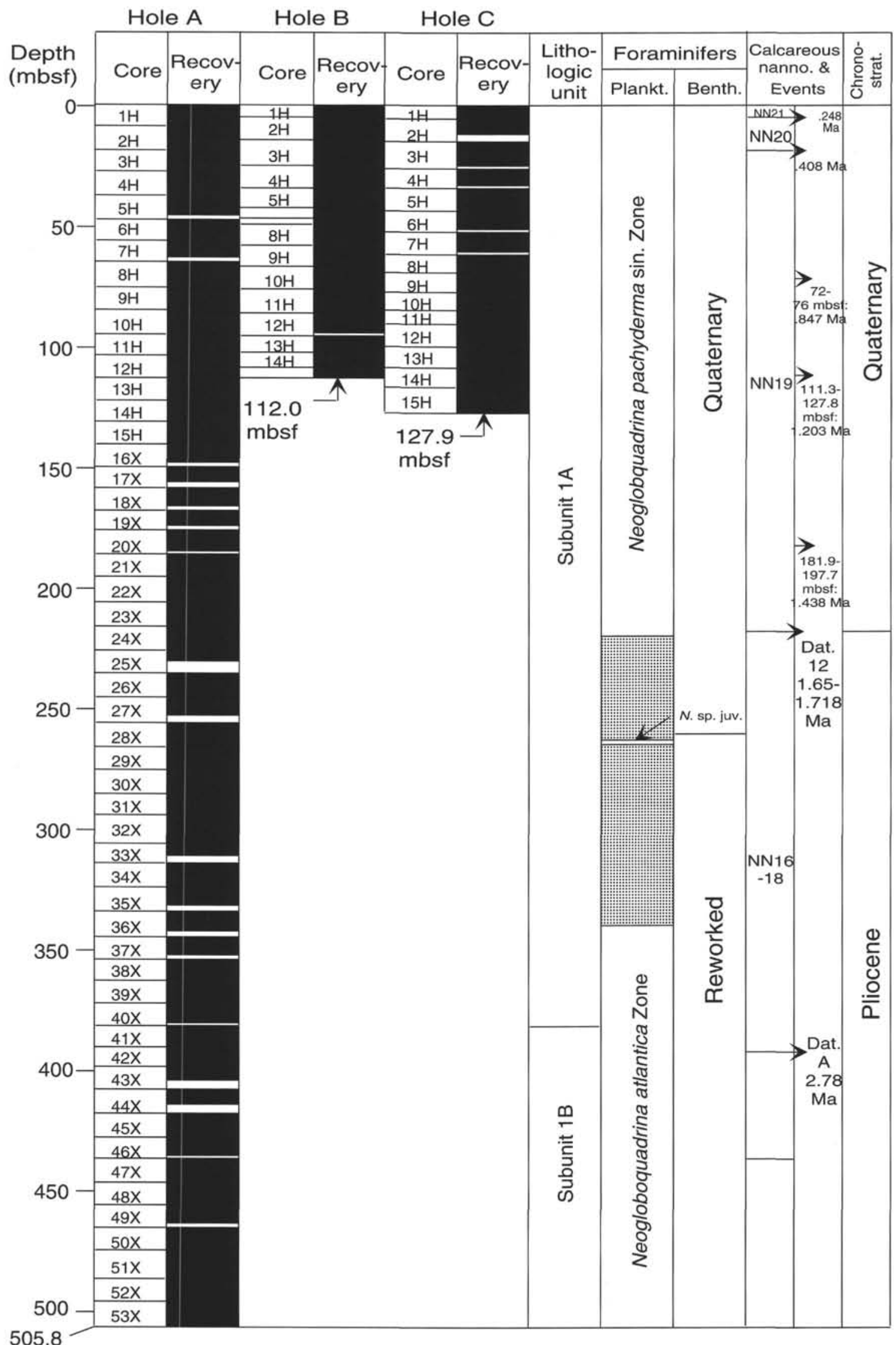

Figure 6. Biostratigraphic synthesis of Holes 911A, 911B, 911C. Biostratigraphic data are from Chapter 9 in Initial Reports volume (Myhre, Thiede, Firth, et al., 1995), Spiegler (this volume), and Sato and Kameo (this volume). See Figure 2 caption for pattern explanations. 
and foraminifers (Myhre, Thiede, Firth, et al., 1995). Datum A (2.78 $\mathrm{Ma}$ ) is reported in Sample 151-911A-42X-2, 89-90 cm (391.9 mbsf).

\section{Site 912}

Site 912 on the Yermak Plateau contains Quaternary and Pliocene sediments (Table 1; Figs. 1, 7). No additional biostratigraphic work has been done on Site 912 and the biostratigraphy remains the same as previously reported (Myhre, Thiede, Firth, et al., 1995). The Pliocene/Quaternary boundary is placed at $131 \mathrm{mbsf}$ based on the occurrence of juvenile dextral coiling Globoquadrina planktonic foraminifers in Sample 151-912A-15X-5, 33-37 cm (131.9 mbsf). The Quaternary/Pliocene boundary occurs slightly above a similar occurrence of juvenile specimens at both Site 910 on the Yermak Plateau and Site 644 on the Vøring Plateau.

\section{Site 913}

Two holes were drilled at Site 913 on the East Greenland Margin in the western portion of the Greenland Basin (Table 1; Figs. 1, 8). Hole $913 \mathrm{~A}$ was drilled to 103.6 mbsf with $25.3 \%$ recovery; Hole 913B reached 770.3 mbsf with $32 \%$ recovery. The drill site is the northernmost point of a north-south transect planned along the East Greenland Margin. It is located on crust that formed during symmetric seafloor spreading along the Mohns Ridge, beginning at about Anomaly 24B time (53-55 Ma; Talwani and Eldholm, 1977; Eldholm and Thiede, 1980). Many of the original objectives in drilling this site (e.g., to describe the onset of deep-water formation in the Greenland Basin) were not possible because of poor recovery in the upper parts of the holes. However, the crew and scientific party were successful in recovering Paleogene sediments valuable for studying the pre-glacial environments of the early Norwegian-Greenland Sea (Myhre, Thiede, Firth, et al., 1995).

Four lithologic units were described from this site (Fig. 8; Myhre, Thiede, Firth, et al., 1995). Unit I and most of Unit II are Pliocene(?) to Quaternary in age; the base of Unit II includes a short interval within a wash core that is dated as middle to late Miocene (Core 151913B-19W); Unit III ranges from the early Eocene to earliest Oligocene; finally, Unit IV is early Eocene. As is typical throughout the Norwegian-Greenland Sea, the Quaternary and Pliocene sediments are dated on the basis of foraminifers and calcareous nannofossils. Miocene and Paleogene sediments contain benthic and planktonic foraminifers, diatoms, radiolarians, silicoflagellates, ebridians, and dinoflagellates. Unfortunately, it was not possible to produce an interpretable magnetic record from Site 913 due to poor recovery and very weak magnetization which prevented determination of a reliable magnetostratigraphy (Myhre, Thiede, Firth, et al., 1995).

Subunit IA (0-3.2 mbsf) consists of Quaternary silt, sand, and foraminifer- and nannofossil-bearing clays. Planktonic and benthic foraminifers compose up to $40 \%$ of the sediment in this subunit. Subunit IB (3.2 to $143.8 \mathrm{mbsf}$ ) consists of Quaternary to Pliocene dark gray mud and silty mud with granule- and pebble-sized dropstones of diverse lithologies. Biogenic components are rare, but include planktonic and benthic foraminifers, an interval with calcareous nannofossils, and molluscan fragments between 23.41 and $23.46 \mathrm{mbsf}$ (Myhre, Thiede, Firth, et al., 1995). Planktonic foraminifers occur sporadically from Cores 151-913A-1H to $12 \mathrm{X}$ and $151-913 \mathrm{~B}-1 \mathrm{R}$ to $2 \mathrm{R}$, and are assigned to the Neogloboquadrina pachyderma sin. Zone ( 0 to approximately $94 \mathrm{mbsf}$ ). Calcareous nannofossils in Cores 151-913A$1 \mathrm{H}$ and $2 \mathrm{X}$ include Emiliania huxleyi and are placed in the NN21 Zone. Cores 151-913A-6X to $12 \mathrm{X}$ (36.1 to $94 \mathrm{mbsf}$ ) and 151-913B$1 \mathrm{R}$ and 2R (95.6-105.2 mbsf; Myhre, Thiede, Firth et al., 1995) have

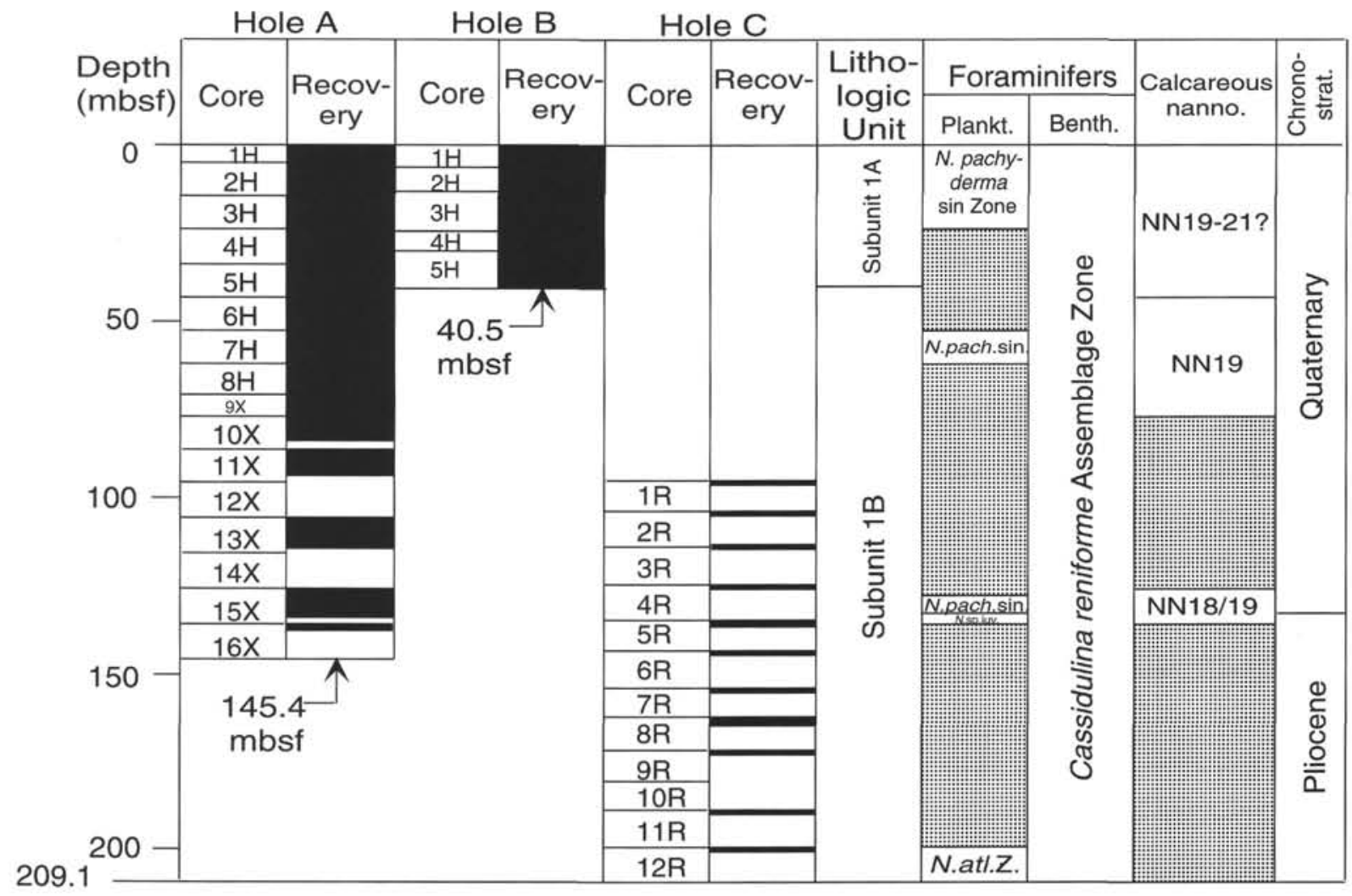

Figure 7. Biostratigraphic synthesis of Holes 912A, 912B, and 912C. Biostratigraphic data are from Chapter 10 in Initial Reports volume (Myhre, Thiede, Firth, et al., 1995), Spiegler (this volume), and Sato and Kameo (this volume). See Figure 2 for pattern explanations. 


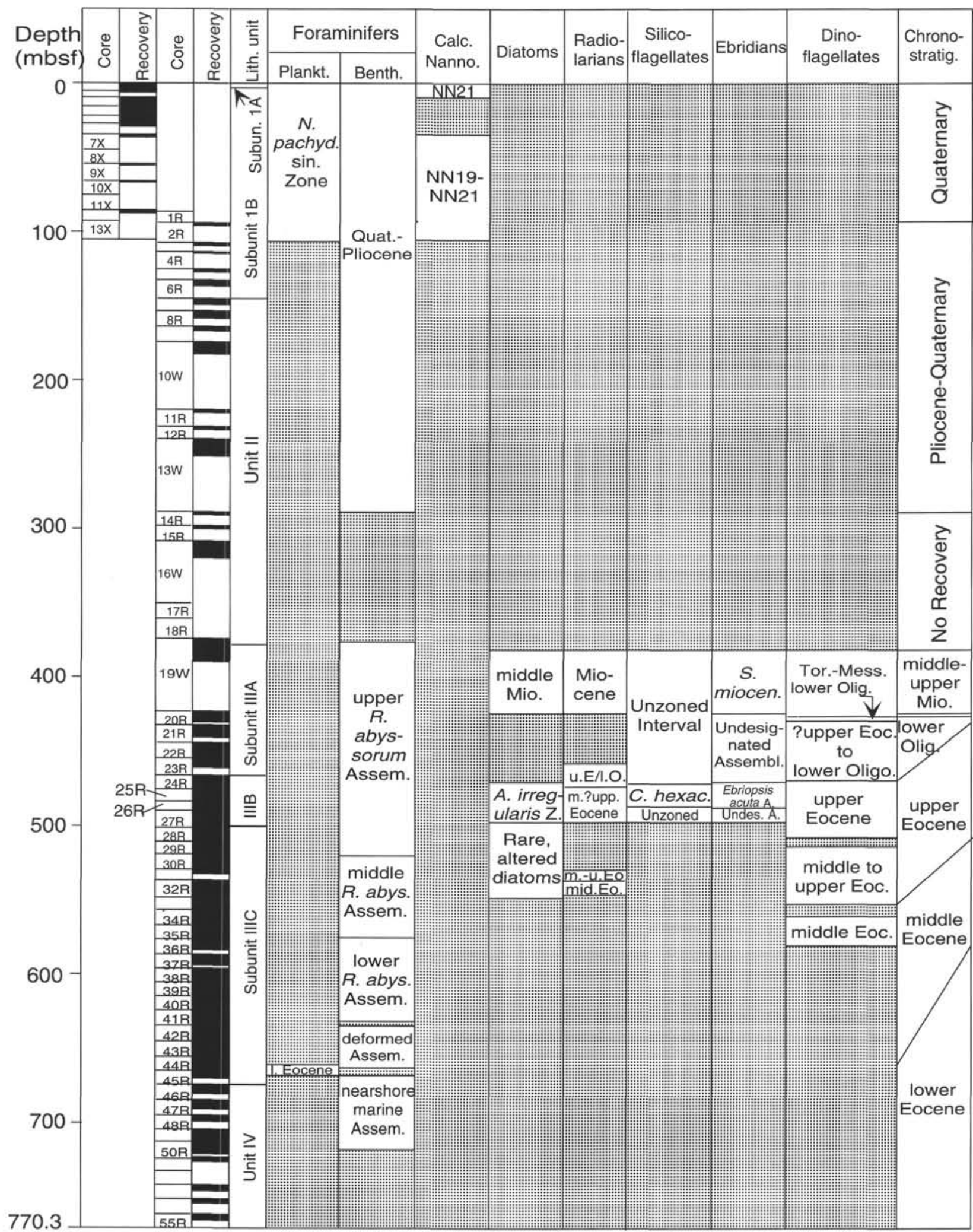

Figure 8. Biostratigraphic synthesis of Hole 913B. Biostratigraphic data are from Chapter 11 in Initial Reports volume (Myhre, Thiede, Firth, et al., 1995) and from works in this volume: Firth, Hull, Locker, Osterman and Spiegler, Poulsen et al., Scherer and Koç, and Spiegler. Diagonal lines indicate ranges of chronostratigraphic boundaries. See Figure 2 for pattern explanations. 
Gephyrocapsa caribbeanica and/or G. oceanica in the absence of $E$. huxleyi, and are correlated to NN19-20 Zones.

The remainder of Subunit IB (105.2 to $143.8 \mathrm{mbsf}$ ) to the base of Core 151-913B-13W in Unit II is Pliocene (?) to Quaternary in age. The only microfossils recovered in this part of the succession are benthic foraminifers, including erratic occurrences of the Pliocene foraminifer Cibicides grossa, which may be reworked (Myhre, Thiede, Firth, et al., 1995).

Recovery in Cores 151-913B-14R and 15R consisted of pieces of gravel. In an attempt to get the drill bit through the dropstone interval and improve recovery, a series of wash cores were taken. Core 151913B-19W (375.2-423.5 mbsf) produced a 7-m-thick interval of clayey to sandy muds. The upper $4 \mathrm{~m}$ of this core belong to lithologic Unit II and are barren of microfossils. The lower $2.5 \mathrm{~m}$ contain benthic foraminifers, diatoms, radiolarians, silicoflagellates, ebridians, and dinoflagellates, which suggest a middle to late Miocene age for Sections 151-913B-19W-4, 19W-5, and 19W-CC.

Sections $151-913 \mathrm{~B}-20 \mathrm{R}-1$ to $20 \mathrm{R}-2$ ( 425.98 to $424.49 \mathrm{mbsf}$ ) are assigned to the early Oligocene based on the occurrence of the dinoflagellate $C$. lobospinosum. Sections 151-913B-20R-3 to 24R-1 (462.68 to $427.45 \mathrm{mbsf}$ ) are late Eocene to early Oligocene. Palynological evidence indicates that the top of the Eocene can be placed above Sample 151-913B-24R-2, 77-79 cm. The dinocyst datums used to recognize the Eocene/Oligocene boundary worldwide include Areosphaeridium diktyoplokus, Cordosphaeridium funiculatum and Batiacasphaera compta (Williams and Bujak, 1985; Brinkhuis and Biffi, 1993; Firth, this volume). The first two species occur in Hole 913B up to Section 151-913B-24R-2; B. compta ranges into Section 151-913B-24R-1. Radiolarians from Core 151-913B-23R to $24 \mathrm{R}-4$ include both upper Eocene and lower Oligocene species, supporting the placement of the boundary within this interval (Hull, this volume).

Sediments from Section 151-913B-24R-2 to 28R-4 (505.15 to 464.27 mbsf) are upper Eocene. Preservation of siliceous microfossils within this interval appears to be the best of the entire Paleogene section, and the age is suggested by dinoflagellates, silicoflagellates, ebridians, diatoms, and radiolarians. A highly diverse assemblage of silicoflagellates is documented by Locker (this volume) from Sample 151-913B-24R-CC to 26R-6, 110-112 cm. The assemblage includes Corbisema hexacantha, C. regina, Dictyocha challengeri, Naviculopsis foliacea, and other species. According to Locker, the consistent occurrence of $C$. hexacantha in this interval indicates the presence of the middle to upper Eocene Corbisema hexacantha Zone. Ebridian assemblages are highly diverse from Sample 151-913B$24 \mathrm{R}-4,111-114 \mathrm{~cm}$, to $27 \mathrm{R}-2,113-117 \mathrm{~cm}$, and include common Hermesinopsis sp. B and Ebriopsis species (E. acuta most dominant). This assemblage correlates with the Corbisema hexacantha Zone.

Scherer and Koç (this volume) propose that diatoms recovered from Samples 151-913B-27R-5, 147-148 cm, to $24 \mathrm{R}-3,65-66 \mathrm{~cm}$ be assigned to their new Actinoptychus irregularis Zone. This zone ranges from upper upper Eocene to lower lower Oligocene, but Scherer and Koç state that because the upper and lower contacts of the zone coincide with lithologic changes in Hole 913B, these contacts cannot be formally defined. The assemblage includes relatively abundant holoplanktonic taxa, and species with both Eocene and Oligocene affinities, suggesting deposition at or very near the Eocene/ Oligocene boundary. Radiolarians from the top of Core 151-913B24R to Section 151-913B-27R-2 include Siphocampe elizabethae, S. imbricata, S. acephala, S. stathmeporoides, Stylodictya targaeformis, Corythospyris palmipodiscus, Lophophaena macrencephala, and some identifiable Lophocyrtis spp. Based on the known ranges of these species, rough correlations to the zonation of Dzinoridze et al. (1978) and the work of Petrushevskaya (1979), and faunal similarities between the 913B assemblage and Site 339 (see discussion in Hull, this volume), the assemblage is best assigned to the late Eocene.
The middle/upper Eocene boundary is placed in an interval from Sample 151-913B-29R-1, 99-102 cm, to 33R-2, 100-104 cm ( 550.90 to $510.89 \mathrm{mbsf}$ ). This is based on dinocysts, although the exact placement of the boundary is difficult according to Firth (this volume), because markers generally used are absent or are based on highest occurrences. Firth avoids using the latter because of reworking in the succession. Radiolarian data indicate an assignment of middle Eocene for Cores 151-913B-31R and upper 32R, and middle to lower upper Eocene for Core 151-913B-30R (Hull, this volume). According to Scherer and Koç (this volume), pyritized diatom assemblages in Core 151-913B-32RC suggest a middle Eocene age based on the rare occurrence of Triceratium inconspicuum, Brightwellia sp., and several species of small Triceratium. They tentatively correlate this assemblage to the $T$. excavata forma tetragona Zone of Fenner (1985).

Below the middle to upper Eocene interval, Sections 151-913B$34 \mathrm{R}-2$ to $36 \mathrm{R}-3$ ( 581.42 to $560.68 \mathrm{mbs}$ ) are assigned to the middle Eocene. Lower Eocene sediments are indicated by planktonic foraminifers in Samples 151-913B-44R-3, 55-60 cm (658.09 mbsf) and 45R-1, 11-14 cm (664.51 mbsf). Sediments from 664.99 to 721.9 mbsf are most likely lower Eocene based on their position between the lower Eocene planktonic foraminiferal occurrences and underlying Anomaly 24B crust (Spiegler, this volume; Myhre, Thiede, Firth, et al., 1995).

The benthic foraminifers of Hole 913B were divided into five main assemblages, which show an increase and then decrease in diversity uphole (Osterman and Spiegler, this volume). The lowest sediments from 716.98 to the base of the hole at 770.3 mbsf are barren of any biota. Above these barren sediments is a poorly fossiliferous sequence from Samples 151-913B-45R-1, 59-62 cm, to 50R-4, 10$14 \mathrm{~cm}$ ( 664.99 to $716.47 \mathrm{mbsf})$. These samples contain scattered agglutinated benthic foraminifers. This sequence is interpreted to represent nearshore marine sediments with megaspores and Skolithos burrows. The first observation of Karrerulina conversa occurs in this interval in Sample 151-913B-46R-3, 12-14 cm. As noted above, these are thought to be lower Eocene sediments. Karrerulina conversa also occurs in abundance in the lower Eocene of the North Sea (Gradstein et al., 1994).

The deformed agglutinated benthic foraminiferal assemblage occurs from Sample 151-913B-41R-CC to 44R-5, 116-120 cm (635.4 to $661.76 \mathrm{mbsf}$ ). These sediments are interpreted to be early to middle Eocene in age. This assemblage consists of a more diverse assemblage with 19 taxa which have been post-depositionally crushed. This assemblage includes the first observations of Haplophragmoides porrectus, Reticulophragimum amplectens, and the entire range of the Eocene marker Spiroplectammina spectabilis.

The upper three assemblages all contain $R$. abyssorum and are assigned the names of the upper, middle, and lower $R$. abyssorum assemblage. The lower $R$. abyssorum assemblage occurs from Sample 151-913B-35R-6, 59-61 cm, to 41R-4, 59-63 cm (575.83 to 629.96 mbsf). This zone contains a diverse assemblage of 41 taxa with $89 \%$ of the samples containing agglutinated benthic foraminifers. The final observations of $R$. amplectens, $K$. conversa, and $H$. porrectus are in this zone, as well as the entire range of $R$. amplectens and Cribrostomoides $\mathrm{sp}$. The lower $R$. abyssorum assemblage occurs in middle Eocene sediments.

The middle $R$. abyssorum assemblage is found in Samples 151913B-30R-1, $12-15 \mathrm{~cm}$ to $35 \mathrm{R}-6,11-13 \mathrm{~cm}$ (519.63 to 575.35 mbsf). This zone occurs in the middle to late Eocene and contains only 18 taxa in $66 \%$ of the samples. Diversity drops even further in the upper $R$. abyssorum Zone from Samples 151-913B-19W-1, 11$15 \mathrm{~cm}$ to $29 \mathrm{R}-\mathrm{CC}$ ( 375.31 to $519.5 \mathrm{mbsf}$ ). This zone contains only eight taxa in $27 \%$ of the samples, the remainder being barren of foraminifers. This zone contains middle to upper Eocene, Oligocene, and Miocene sediments. 


\section{LEG 151 EPOCH SUMMARIES}

\section{Eocene-Oligocene (Sites 913, 908)}

The oldest sediments recovered on Leg 151 are lower Eocene clays and silty clays from Site 913 (Fig. 8). Planktonic foraminifers in Cores 151-913B-44R and 45R are early Eocene in age (Spiegler, this volume); sediments from 664.99 to 721.9 mbsf are most likely early Eocene based on the Anomaly $24 \mathrm{~B}$ crust below and the occurrence of lower Eocene planktonic foraminifers above. Biosiliceous sediments recovered from lithologic Unit III in Cores 151-913B-20R to $36 \mathrm{R}$, range from middle Eocene to lowest Oligocene, based on biostratigraphic studies of dinoflagellates, diatoms, radiolarians, silicoflagellates, and ebridians. Although all of the fossil groups contain Eocene markers, the most persuasive evidence for the presence of lower Oligocene material in this hole (Core 151-913B-20R) is from dinoflagellate stratigraphy (Firth, this volume). Stage and sub-stage boundaries in this hole are also based largely on dinoflagellate markers, although they are supported in general by other groups.

Upper lower to lower upper Oligocene sediments were recovered from Cores 151-908A-20X to 37X in Hole 908A (Fig. 3). According to dinoflagellate stratigraphy and their stage calibrations, the age ranges from the upper Rupelian to lower Chattian. Dinoflagellate determinations are supported by diatoms, but silicoflagellates and ebridians suggest that the entire sequence is upper Oligocene and does not extend into older sediments. Other groups present at this site-benthic foraminifers and radiolarians - have lower resolution biostratigraphy and can only support an Oligocene assignment.

If dinoflagellate age determinations are correct, then a portion of the early early Oligocene-i.e., the early part of the Rupelian above the youngest sediments at Site 913 and below the oldest sediments at Site 908, has not been recovered on Leg 151. If silicoflagellate age determinations for Site 908 are correct, then all of the early Oligocene (Rupelian) above the earliest Oligocene at Site 913 has not been recovered. Also, biostratigraphic evidence suggests that we may not have recovered late late Oligocene (equivalent to late Chattian) material.

\section{Miocene (Sites 907, 908, 909, 913)}

Miocene material has been recovered from four holes on Leg 151: (1) middle middle to upper Miocene biosiliceous sediments are present in Hole 907A (Cores 151-907A-10H to 23H; Fig. 2); (2) a late Miocene interval has been documented overlying the unconformity in Hole 908A which contains dinoflagellates and rare diatoms, silicoflagellates, and ebridians (Fig. 3); (3) a very long (nearly $700 \mathrm{~m}$ ) lower?/middle Miocene to upper Miocene succession containing rare calcareous nannofossils, planktonic foraminifers, and abundant dinoflagellates occurs in Hole 909C from Core 151-909C-27R (342 mbsf) to the bottom of the hole (1061.8 mbsf; Fig. 4); and (4) a wash core taken at 375.2 to 423.5 mbsf in Hole 913B has yielded middle to upper Miocene diatoms, radiolarians, ebridians, agglutinated foraminifers, and dinoflagellates (Fig. 8).

The only possible occurrence of lower Miocene sediments on Leg 151 is in the base of Hole 909C where the calcareous nannofossil Helicosphaera carteri was discovered in Sections 151-909C-101R-2 through 102R-CC by the shipboard scientific party (Myhre, Thiede, Firth, et al., 1995). Palynomorphs in this part of the section are less definitive, indicating an age of Aquitanian? to Langhian? (early to middle Miocene; Poulsen et al., this volume).

Middle Miocene is unquestionably present in Holes 907A (Cores $151-907 \mathrm{~A}-15 \mathrm{H}$ to $27 \mathrm{H}$ ) and $909 \mathrm{C}$ (Cores $151-909 \mathrm{C}-97 \mathrm{R}$ to $70 \mathrm{R}$ ), and possibly in Hole 913B (Core 151-913B-19W). In Holes 907A on the Iceland Plateau and 913B on the East Greenland Margin, middle Miocene material is highly biosiliceous, containing diatoms, sili- coflagellates, ebridians, and radiolarians. Middle Miocene sediments in Hole 909C in the Fram Strait, however, are devoid of all biosiliceous material. Upper Miocene sediments from Hole 907A (Cores 151-907A-15H to $10 \mathrm{H}$ ), possibly 913B (Core 151-913B-19W), and Hole 908A in the Fram Strait are also biosiliceous, while Hole 909C remains barren of biosilica. Thus, the differences in tectonic histories of Holes 908A and 909C in the Fram Strait are well-illustrated by stratigraphic evidence: the former has a short sequence of upper Miocene material containing small amounts of biosilica that unconformably overlies biosilica-rich Oligocene sediments; the latter has a long, preserved history of middle to late Miocene deposition in an environment where biosilica productivity was absent, or too low to allow for preservation on the seafloor. A model for the evolution of the Hovgård Ridge that may explain these differences has been proposed by Myhre et al. (1982) and Myhre and Eldholm (1988; see also Myhre, Thiede, Firth, et al., 1995, chapters 1, 6).

The Oligocene/Miocene boundary was not recovered on ODP Leg 151. The middle/upper Miocene boundary is present in Hole 907A (Core 151-907A-15H) in the southern part of the NorwegianGreenland Sea, where its placement is determined on the basis of diatoms and magnetostratigraphy. This boundary is also reasonably well distinguished at Site 909, between Samples 151-909C-70R-CC and $69 \mathrm{R}-\mathrm{CC}$, based on dinoflagellate biostratigraphy. The Miocene/ Pliocene boundary is present in Holes 907A, 908A, and 909C. It is best distinguished in Hole $907 \mathrm{~A}$ by diatoms and magnetostratigraphy; in Holes $908 \mathrm{~A}$ and $909 \mathrm{C}$ the boundary is more broadly defined by dinoflagellates.

\section{Pliocene and Quaternary (all sites)}

Quaternary and Pliocene sediments are found at all Leg 151 sites. Because of the poor recovery and the difficulty in differentiating between Quaternary and Pliocene sediments, they will be discussed together. There are no recognized unconformities in the Pliocene and Quaternary, with the exception of Site 910.

At Site 907 on the Iceland Plateau, Quaternary and Pliocene sediments can be differentiated based on diatoms. Pliocene nonglacial sediments are rich in siliceous microfossils with only brief episodes of carbonate preservation. Quaternary sediments contain less abundant siliceous microfossils and more common calcareous ones. An episode of calcareous dissolution occurs in the late Pliocene.

Site 908 (Hovgård Ridge) contains undifferentiated Quaternary and late Pliocene based on the calcareous microfossils, and undifferentiated late Miocene to early Pliocene (Messinian-Zanclean) based on dinoflagellates.

Drilling at Site 909 (Fram Strait) recovered a complete sequence of both Quaternary and Pliocene sediments. Glacial Quaternary and Pliocene sediments contain calcareous microfossils and are separated from each other by an episode of calcareous dissolution. Pre-glacial Pliocene sediments are recognized by dinoflagellates.

The Pliocene/Quaternary boundary at Site 910 (Yermak Plateau) is placed at $67 \mathrm{mbsf}$ based on calcareous microfossils and benthic foraminifers. Several unconformities are believed to occur from 19 to 102.8 mbsf within the Pliocene and Quaternary sediments. Upper Pliocene sediments are found to the base of the hole (507.4 mbsf). Calcareous nannofossils, ostracodes, and benthic and planktonic foraminifers indicate that warmer temperatures were present in the preglacial late Pliocene at this site.

Site 911 (Yermak Plateau) contains Pliocene and Quaternary glacial sediments. The Pliocene/Quaternary boundary between 217 and $217.5 \mathrm{mbsf}$ is based on the occurrence of calcareous nannofossil Datum 12 (Sato and Kameo, this volume) and is supported by paleomagnetics and foraminifers (Myhre, Thiede, Firth, et al., 1995). Quaternary and upper Pliocene glacial sediments are separated by a carbonate dissolution event. 
Site 912 (Yermak Plateau) contains Quaternary and Pliocene glacial sediments. The Pliocene/Quaternary boundary is placed at 131 mbsf, based on the planktonic foraminifers, and is separated by a carbonate dissolution event.

Site 913 on the East Greenland Margin contains undifferentiated Quaternary and Pliocene sediments based on calcareous microfossils. Poor recovery due to the abundant (some large) dropstones suggest strong glacial influences during this interval.

\section{KEY DIFFERENCES WITH SHIPBOARD REPORTS}

As more complete and detailed studies are conducted on shore, it is not uncommon for boundaries to move to new positions that better represent the data. These changes are shown on Table 2; final interpretations for all sites are illustrated on Figure 9. Also compare and contrast the figures in this chapter with those from the Initial Reports Site Chapters (Myhre, Thiede, Firth et al., 1995) as follows: (1) Site 907_ Fig. 13, Chapter 5, p. 74, with Fig. 2 herein; (2) Site 908-Fig. 10, Chapter 6, p. 123, with Fig. 3 herein; (3) Site 909-Fig. 8, Chapter 7, p. 172, with Figure 4 herein; (4) Site 910-Fig. 14, Chapter 8, p. 236, with Fig. 5 herein; (5) Site 911-Fig. 9, Chapter 9, p. 281, with Fig. 6 herein; (6) Site 912-Fig. 7, Chapter 10, p. 328, with Fig. 7 herein; and (7) Site 913-Fig. 13, Chapter 11, p. 361, with Fig. 8 herein.

\section{CONCLUSIONS}

Sediments ranging in age from early Eocene to Quaternary were recovered on Leg 151 of the Ocean Drilling Program. Southern Norwegian-Greenland Sea Site 907 on the Iceland Plateau yielded a middle Miocene to Quaternary sequence interrupted by two or three short hiatuses and one of the best paleomagnetic records yet recovered from the Norwegian-Greenland Sea. Biosiliceous middle and upper Miocene sediments at this site are replaced in the Pliocene and Quaternary by steadily decreasing amounts of biosilica and increasing preservation of biogenic carbonate. Two sites drilled adjacent to one another in the Fram Strait, Sites 908 and 909, revealed two different stratigraphic sequences, providing support for earlier ideas about the tectonic evolution of the Hovgård Ridge (Myhre et al., 1982; Myhre and Eldholm, 1988). Cores from Site 909 indicate a long, relatively uninterrupted history of middle (or older) to late Miocene deposition in an environment where biosilica productivity was absent, or too low to allow for preservation on the seafloor. Site 908 , in contrast, has a very short sequence of upper Miocene material (with small amounts of biosilica) overlying an unconformity which spans the late late Oligocene to middle Miocene. Oldest sediments underlying the unconformity in Hole 908A are late early to early late Oligocene in age, and rich in biosiliceous and terrigenous material.

Yermak Plateau Sites 910,911, and 912 revealed thick sequences of Pliocene and Quaternary sequences of hemipelagic glacial sediment bearing calcareous nannofossils, foraminifers, and dinoflagellates. These cores present evidence for brief episodes of carbonate dissolution and preservation and are almost completely devoid of biosilica, a fact that may not be indicative of a lack of productivity in the surface waters but rather the inability of silica to be preserved on the seafloor during this period. Intervals of good carbonate preservation have allowed for the calibration of several nannofossil datums on the Yermak Plateau, which may prove valuable in the correlation of other high-latitude regions.

Finally, lower Eocene to lowest Oligocene sediments, faunas and floras recovered from Site 913 provided another glimpse into the early history of the Norwegian-Greenland Sea, and the first from the East Greenland Margin. Eight different fossil groups are represented in this sequence, although the oldest portion of the record contains only a few planktonic foraminifers and abundant (but non-age diagnostic) agglutinated foraminifers. Microfossils are more abundant in the late Eocene, and ages provided by most of the groups are in agreement for this time. Unfortunately, lithologic and environmental changes in the latest Eocene and earliest Oligocene make recognition of the Eocene/Oligocene boundary difficult, but a boundary interval is possible to discern on the basis of dinoflagellate biostratigraphy. There can be no doubt that Paleogene biostratigraphy in the Norwegian-Greenland Sea is in need of further refinement, but such highresolution biostratigraphy will not be accomplished until greater efforts are made to drill continuous Paleogene records in transects across the basin.

\section{ACKNOWLEDGMENTS}

This synthesis would not have been possible without the dedicated shipboard and shorebased scientists who contributed to this volume; our thanks for their time and effort, for supplying us with copies

Table 2. Key differences between biostratigraphic analyses in shipboard reports and this synthesis.

\begin{tabular}{|c|c|c|}
\hline Site & Shipboard reports & Changes in this synthesis \\
\hline 907 & $\begin{array}{l}\text { Age range: middle middle Miocene-Quatemary. Pliocene/Quatemary boundary: } 37 \text { mbsf. } \\
\text { Miocene/Pliocene boundary: } 83.3 \text { mbsf (top of Core } 151-907 \mathrm{~A}-10 \mathrm{H} \text { ). Middle/upper } \\
\text { Miocene boundary: } 129.5 \text { mbsf (in Core } 151-907 \mathrm{~A}-14 \mathrm{H} \text { ). Base of section no older than } \\
16 \mathrm{Ma} \text {. }\end{array}$ & $\begin{array}{l}\text { Middle/upper Miocene boundary lowered to } 130.8 \text { mbsf (top of Core } 151 \text { - } \\
907 \mathrm{~A}-15 \mathrm{H} \text { ) based on diatoms. Reinterpretation of magnetostratigraphy by } \\
\text { Koç and Scherer (this volume) places base in Chron } 5 \mathrm{AD}(14.8 \mathrm{Ma}) \text {. } \\
\text { Basalt age: } 13.2 \pm 0.3 \mathrm{Ma}{ }^{40 / 39} \mathrm{Ar} \text { analysis. }\end{array}$ \\
\hline 908 & $\begin{array}{l}\text { Quaternary and Pliocene (to late Miocene?) sediments with rare calcareous microfossils } \\
\text { unconformably overlying upper Oligocene biosilica-rich muds. Late Miocene-early } \\
\text { Pliocene dinoflagellates at } 148.7 \text { mbsf. Unconformity at } 185 \text { mbsf. }\end{array}$ & $\begin{array}{l}\text { Quatemary/Pliocene boundary: } 52.9-62.4 \text { mbsf. Pliocene to upper Miocene } \\
62.4-132 \text { mbsf; } 132-185 \text { mbsf }=\text { early late Miocene. Below unconformity } \\
\text { (185 mbsf), sediments are late early to early late Oligocene based on } \\
\text { diatoms and dinoflagellates. }\end{array}$ \\
\hline 909 & $\begin{array}{l}\text { Quaternary: } 0-83 \mathrm{mbsf} \text {. Barren zone from } 200.8-277.8 \mathrm{mbsf} \text { contains Quaternary/Pliocene } \\
\text { boundary. Pliocene/Miocene boundary at } 354.9-451 \mathrm{mbsf} \text {. Bottom of sequence: late } \\
\text { Oligocene to early Miocene. }\end{array}$ & $\begin{array}{l}\text { Detailed dinoflagellate stratigraphy has improved age constraints. Upper } \\
\text { Pliocene to Miocene: } 345.3 \text { to } 566.6 \text { mbsf; upper to middle Miocene: } 573 \\
\text { to } 867.9 \text { mbsf. Base of hole constrained to earliest Miocene. }\end{array}$ \\
\hline 910 & $\begin{array}{l}507.4 \mathrm{~m} \text { succession of Quaternary and Pliocene glacial marine and hemipelagic muds. 0- } \\
64.2 \mathrm{mbsf} \text { = Quaternary; Pliocene/Quaternary boundary between } 64.2 \text { and } 93.1 \mathrm{mbsf} \text {. }\end{array}$ & $\begin{array}{l}\text { Pliocene/Quaternary boundary refined. Herein placed at } 67 \mathrm{mbsf} \text { based on } \\
\text { foraminiferal and calcareous nannofossil studies. }\end{array}$ \\
\hline 911 & $\begin{array}{l}505.8 \mathrm{~m} \text { section of Quaternary and Pliocene sediments with rare to common foraminifers } \\
\text { and calcareous nannofossils. Pliocene/Quaternary boundary between } 216.8 \text { and } 265.1 \\
\text { mbsf. }\end{array}$ & $\begin{array}{l}\text { Refinement in location of Pliocene/Quatemary boundary: herein placed } \\
\text { between } 217 \text { and } 217.25 \text { mbsf. }\end{array}$ \\
\hline 912 & $\begin{array}{l}145.4 \mathrm{~m} \text { of Quaternary and Pliocene sediments bearing calcareous microfossils. Pliocene/ } \\
\text { Quaternary boundary placed in Section } 151-912 \mathrm{~A}-15 \mathrm{X}-5(-132 \mathrm{mbsf}) \text {. }\end{array}$ & No changes reported at this site. \\
\hline 913 & $\begin{array}{l}\text { Upper } 288.4 \mathrm{~m} \text { Quatemary and Pliocene; boundary placement not possible. Core } 151 \text { - } \\
913 \mathrm{~B}-19 \mathrm{~W}=\text { middle Miocene. } 471 \text { to } 500 \mathrm{mbsf} \text { assigned to the latest Eocene-earliest } \\
\text { Oligocene; } 500 \text { to } 731.6 \mathrm{mbsf}=\text { middle Eocene. Base of succession barren of all } \\
\text { microfossils. }\end{array}$ & $\begin{array}{l}\text { 0-143.8 mbsf Plioene/Quaternary. Core } 151-913 \mathrm{~B}-19 \mathrm{~W} \text { middle-upper } \\
\text { Miocene. } 426-424.5 \mathrm{mbsf}=\text { lower Oligocene; } 462.7-427.5=\text { lower } \\
\text { Eocene to lower Oligocene; } 505.2-464.3=\text { upper Eocene; middle/upper } \\
\text { Eocene boundary between } 550.9 \text { and } 510.9 \text { mbsf. } 581.4-560.8 \mathrm{mbsf} \\
\text { middle Eocene. Base lower Eocene. }\end{array}$ \\
\hline
\end{tabular}




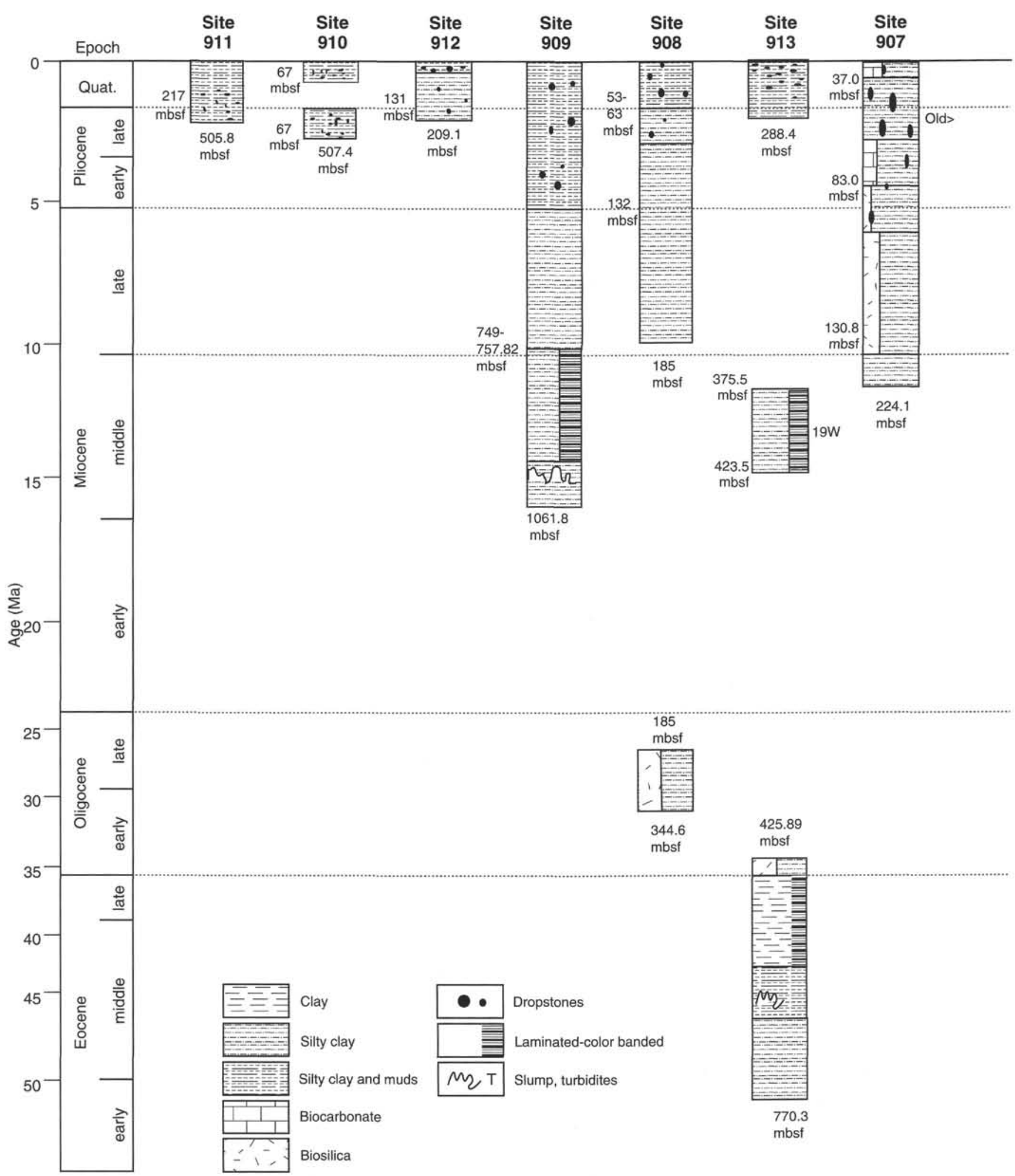

Figure 9. Summary figure of all sites showing revised ages of recovered sequences. 
of their papers, and for answering many questions. Special thanks to the members of the Leg 151 Chronostratigraphy Group, who came together in January of 1995 at GEOMAR in Kiel, Germany, to discuss, share, and debate the stratigraphic evidence collected on Leg 151. Our thanks to reviewers Jan Backman and William B. Berggren for their helpful comments. This work has been supported by the U.S. Science Support Program through Texas A\&M Research Foundation, \#151-20796b.

\section{REFERENCES}

Bjørklund, K.R., 1976. Radiolaria from the Norwegian Sea, Leg 38 of the Deep Sea Drilling Project. In Talwani, M., Udintsev, G., et al., Init. Repts. DSDP, 38: Washington (U.S. Govt. Printing Office), 1101-1168.

Bleil, U., 1989. Magnetostratigraphy of Neogene and Quaternary sediment series from the Norwegian Sea: Ocean Drilling Program, Leg 104. In Eldholm, O., Thiede, J., Taylor, E., et al., Proc. ODP, Sci. Results, 104: College Station, TX (Ocean Drilling Program), 829-901.

Bukry, D., 1981. Synthesis of silicoflagellate stratigraphy for Maestrichtian to Quaternary marine sediments. In Warme, T.E., Douglas, R.C., and Winterer, E.L. (Eds.), The Deep Sea Drilling Project: A Decade of Progress. Spec. Publ.-Soc. Econ. Paleontol. Mineral., 32:433-444.

Brinkhuis, H., and Biffi, U., 1993. Dinoflagellate cyst stratigraphy of the Eocene/Oligocene transition in central Italy. Mar. Micropaleontol., 22:131-183

Cande, S.C., and Kent, D.V., 1992. A new geomagnetic polarity time scale for the Late Cretaceous and Cenozoic. J. Geophys. Res., 97:1391713951.

Dzinoridze, R.N., Jousé, A.P., Koroleva-Golikova, G.S., Kozlova, G.E., Nagaeva, G.S., Petrushevskaya, M.G., and Strelnikova, N.I., 1978. Diatom and radiolarian Cenozoic stratigraphy, Norwegian Basin; DSDP Leg 38. In Talwani, M., Udintsev, G., et al., Init. Repts. DSDP, 38, 39, 40, 41 (Suppl.): Washington (U.S. Govt. Printing Office), 289-427.

Eldholm, O., and Thiede, J., 1980. Cenozoic continental separation between Europe and Greenland. Palaeogeogr., Palaeoclimatol., Palaeoecol., 30:243-259.

Eldholm, O., Thiede, J., Taylor, E., et al., 1987. Proc. ODP, Init. Repts., 104: College Station, TX (Ocean Drilling Program)

Fenner, J., 1985. Late Cretaceous to Oligocene planktic diatoms. In Bolli, H.M., Saunders, J.B., and Perch-Nielsen, K. (Eds.), Plankton Stratigraphy: Cambridge (Cambridge Univ. Press), 713-762.

Goll, R.M., 1989. A synthesis of Norwegian Sea biostratigraphies: ODP Leg 104 on the Vøring Plateau, In Eldholm, O., Thiede, J., Taylor, E., et al., Proc. ODP, Sci. Results, 104: College Station, TX (Ocean Drilling Program), 777-826.

Goll, R.M., and Bjørklund, K.R., 1989. A new radiolarian biostratigraphy for the Neogene of the Norwegian Sea: ODP Leg 104. In Eldholm, O.. Thiede, J., Taylor, E., et al., Proc. ODP, Sci. Results, 104: College Station, TX (Ocean Drilling Program), 697-737.

Gradstein, F.M., Kaminski, M.A., Berggren, W.A., Kristiansen, I.L., and D'Ioro, M.A., 1994. Cenozoic biostratigraphy of the North Sea and Labrador Shelf. Micropaleontology, 40 (Suppl.):1-152.
Kaiho, K., 1991. Global changes of Paleogene aerobic/anaerobic benthic foraminifera and deep-sea circulation. Palaeogeogr., Palaeoclimatol. Palaeoecol., 83:65-85.

King, C., 1983. Cainozoic micropaleontological biostratigraphy of the North Sea. Inst. Geol. Sci. Rep., 82.

Knudsen, K.L., and Asbjörnsdottir, L., 1991. Plio-Pleistocene foraminiferal stratigraphy and correlation in the Central North Sea. Mar. Geol., 101:113-124.

Manum, S.B., Boulter, M.C., Gunnarsdottir, H., Rangnes, K., and Scholze, A., 1989. Eocene to Miocene palynology of the Norwegian Sea (ODP Leg 104). In Eldholm, O., Thiede, J., Taylor, E., et al., Proc. ODP, Sci. Results, 104: College Station, TX (Ocean Drilling Program), 611-662.

Miller, K.G., 1983. Eocene-Oligocene paleoceanography of the deep Bay of Biscay: benthic foraminiferal evidence. Mar. Micropaleontol., 7:403440.

Miller, K.G., Gradstein, F.M., and Berggren, W.A., 1982. Late Cretaceous to early Tertiary agglutinated benthic foraminifera in the Labrador Sea. Micropaleontology, 28:1-30.

Myhre, A.M., and Eldholm, O., 1988. The western Svalbard margin $\left(74^{\circ}-\right.$ $80^{\circ}$ N). Mar. Pet. Geol., 5:134-156.

Myhre, A.M., Eldholm, O., and Sundvor, E., 1982. The margin between Senja and Spitsbergen fracture zones: implication from plate tectonics. Tectonophysics, 89:33-50.

Myhre, A.M., Thiede, J., Firth, J.V., et al., 1995. Proc. ODP, Init. Repts., 151: College Station, TX (Ocean Drilling Program).

Osterman, L.E., and Qvale, G., 1989. Benthic foraminifers from the Vøring Plateau (ODP Leg 104). In Eldholm, O., Thiede, J., Taylor, E., et al., Proc. ODP, Sci. Results, 104: College Station, TX (Ocean Drilling Program), 745-768.

Petrushevskaya, M., 1979. Evolution of Radiolaria in the Norwegian-Greenland basin. In Strelkov, A.A., and Petrushevskaya, M.G. (Eds.), The History of the Microplankton of the Norwegian Sea (on the Deep Sed Drilling Materials). Explorations of the Fauna of the Sea, Acad. Sci USSR, Zool. Inst., 23:86-157.

Sato, T., and Takayama, T., 1992. A stratigraphically significant new species of the calcareous nannofossil Reticulofenestra asanoi. In Ishizaki, K. and Saito, T. (Eds.), Centenary of Japanese Micropaleontology: Tokyo (Terra Sci. Publ.), 457-460.

Schrader, H.-J., and Fenner, J., 1976. Norwegian Sea Cenozoic diatom biostratigraphy and taxonomy. In Talwani, M., Udintsev, G., et al., Init. Repts. DSDP, 38: Washington (U.S. Govt. Printing Office), 921-1099.

Talwani, M., and Eldholm, O., 1977. Evolution of the Norwegian-Greenland Sea. Geol. Soc. Am. Bull., 88:969-999.

Wei, W., and Peleo-Alampay, A., 1993. Updated Cenozoic nannofossil magnetobiochronology. INA. Newsl., 15:15-21.

Williams, G.L., and Bujak, J.P., 1985. Mesozoic and Cenozoic dinoflagellates. In Bolli, H.M, Saunders, J.B., and Perch-Nielsen, K. (Eds.), Plankton Stratigraphy: Cambridge (Cambridge Univ. Press), 847-964.

Date of initial receipt: 17 January 1996

Date of acceptance: 17 May 1996

Ms 151SR-146 